Full reference: Adhikariparajul, M., Hassan, A., Fletcher, M., \& Elamer, A.A. (2019) 'Integrated Reporting in UK Higher Education Institutions', Sustainability Accounting, Management and Policy Journal, Forthcoming (Accepted $14^{\text {th }}$ January 2019).

\title{
Integrated Reporting in UK Higher Education Institutions
}

\author{
Mahalaximi Adhikariparajul a, Abeer Hassan ${ }^{\text {a*}}$, Mary Fletcher ${ }^{a}$ and Ahmed Elamer ${ }^{b}$ \\ ${ }^{a}$ Accounting, Finance and Law UnitSchool of Business and Enterprise, University of the West of Scotland, \\ Paisley, PA1 2BE, UK
${ }^{\mathrm{b}}$ School of Management, Faculty of Management, Law and Social Sciences, University of Bradford, Emm Lane, Bradford, BD9 4JL, UK; and Department of Accounting, Faculty of Commerce, Mansoura University, Mansoura, Egypt

*Address for correspondences

Dr. Abeer Has san

Senior Lecturer in Accounting and $\mathrm{PhD}$ coordinator

School of Business and Enterprise;

G226, Gardner Building,

University of the West of Scotland

PAISLEY; PA12BE

Tel: +44 (0)141 8483361

Fax: +44 (0)141 8483395

email:abeer.hassan@uws.ac.uk 


\title{
Integrated Reporting in UK Higher Education Institutions
}

\begin{abstract}
Purpose - This paper examines trends in the content of reporting within 135 UK Higher Education Institutions (HEIs). It explores the extent to which Integrated Reporting (IR) content elements, reflecting integrated thinking, are disclosed voluntarily and whether HEI specific features influence the resulting disclosures.
\end{abstract}

Design/methodology/approach - Existing IR guidelines given by the International Integrated Reporting Council (IIRC) and the adoption of content analysis have provided the opportunity to examine the trend and extent of IR content elements as sociated in HEI corporate reports. The evidence was obtained from 405 UK HEI annual reports covering the period 2014-2016.

Findings-The results indic ate a significant increase in the number of IR content elements embedded in HEI annual reports. The HEI specific characteristics examined, such as a) the establishment of HEI (before or after 1992), b) adoption of IR framew ork and c) size of HEI, are all significantly and positively associated with IR content elements disclosure. This paper argues that institutional theory, isomorphism and isopraxism are relevant for explaining the changes in the contents of HEI annual reports. The findings also suggest that universities are beginning to adopt an integrated thinking approach to the reporting of their activities.

Limitations-The study is based on IR content elements only and could be extended to include the fundamental concepts and basic principles of the IR framew ork. There are other factors that have a potentially crucial influence on HEI core activities (such as teaching and learning research and internationalisation) which have been omitted from this study.

Practical implications- The findings will allow policymakers to evaluate the extent to which integrated thinking is taking place and influencing the UK HEI sector in the selection and presentation of information. A further implication of the findings is that an appropriate a sector-wide enforcement and compliance body, for instance, the British Universities Finance Directors Group (BUFDG), may consider developing voluntary IR guidance in a clear, consistent, concise and comparable format. Also, it may pursue regulatory support for this guidance. In doing so, it may monitor the compliance and disclosure levels of appropriate IR requirements. Within such a framework, IR could be used to assist HEIs to make more sustainable choices and allow stakeholders to better understand aspects of HEI performance.

Social implications- The research has implications for society within and beyond the unique UK HEI sector. Universities are places of advanced thinking and can lead the way for other sectors by demonstrating the potential of integrated thinking to create a cohesive wide-ranging discourse and create engagement among stakeholder groups. Specifically, IR builds on the strong points of accounting, for instance, robust quantitative evidence collecting, relevance, reliability, materiality, comparability and assurability, to explain the sustainability discourse into a "language" logical to HEIs organisational decision-makers. Consequently, IR may generate better visibility and know ledge of the financial values of exploiting capitals (financial, intellectual, human, manufactured, social, and natural) and offer a multifaceted approach to reassess HEIs organisational performance in various sectors that support the growth of integrated thinking.

Originality/value- This is the first known study to explore HEI characteristics and link them with the level of voluntary IR content elements disclosed in UK HEIs.

Keywords- Integrated Reporting, Higher Education Institutions, Content analysis, Institutional theory Paper type- Research paper 


\section{Introduction}

Investors and society demand that corporations should be accountable towards stakeholders and be transparent about their activities (Eccles \& Krzus, 2010; Abeysekera, 2013; Veltri and Silvestri 2015). Hence, from around the 1990s, social and environmental reports were published alongside traditional financial reports with the expectation that organisations should be good citizens, fulfil social roles and tackle social problems thus obtaining social recognition by engaging actively in dialogue with stakeholders (Schmeltz, 2017; Liao et al., 2017). Additionally, over the past two decades, public organisations have started publishing separate environmental and social voluntary reports to convey non-financial information to organisational stakeholders. However, it has been argued that recognising the impact of social issues on corporate activities and organisational performance on actual stakeholder`s information needs, this information should not be restricted to the traditional standalone environmental, social and governance reporting format (Eccles and Krzus, 2010; Dragu and Tiron-Tudor, 2013). In response, Integrated Reporting (IR) develops a holistic corporate picture of combined disclosures. Environmental, social, sustainability and governance information previously kept separate from financial information is united by IR through the publication of a single report highlighting, from a stakeholder's perspective, the organisation in society and sustainable development (King IV, 2016; Soh et al., 2015; Reimsbach et al., 2017). The International Integrated Reporting Council (IIRC) defines IR as "a process founded on integrated thinking that results in a periodic integrated report by an organisation about value creation over time and related communications regarding aspects of value creation" (IIRC, 2018 p. 1). Therefore, in an integrated report, the organisation should explain about value creation, and demonstrate integrated thinking in practice and in a sustainable manner (King IV, 2016 p. 28). 
The existence of IR is described as "seminal" (De Villiers et al., 2014) and has been studied from two research perspectives. One research strand is conceptual in nature with very little or no connection with evidence from IR practice (Adams and Simnett, 2011; Abeysekera, 2013; Adams, 2015). The other research strand is empirical in nature and emerges from both academia and surveys of professional accountancy bodies (Solomon and Maroun, 2012; Deloitte, 2014; KPMG, 2016; Adams et al., 2016; Gunarathe and Senaratne, 2017; Kilic and Kuzey, 2018; Steenkamp, 2018).

By implementing IR, it is argued that organisations can "tell the story" of all the activities undertaken for value creation (King IV, 2016). Recognising and reporting multiple sources of capital, qualitative information about organisations` missions and forward-looking information on IR should be an attractive means to reflect value created for both profit-oriented and non-profit organisations. The British Universities Finance Directors Group (BUFDG) report (2016) emphasises that Higher Education Institutions (HEIs) have an interesting story to tell their stakeholders about the importance of their role in sustainable value creation and IR helps them to tell that story. Universities have a unique place in society. They are not only centres of creative thinking and innovation but also fulfil many additional roles, providing leadership, advice and support. However, this varied contribution has often been little reflected in the communications between universities and wider society (BUFDG, 2016). This suggests that HEIs can benefit from being more transparent when disclosing value creation activities to their stakeholders using IR.

The main aim of this study is to investigate to what extent UK HEIs provide disclosure on IR content elements given by the IIRC, suggesting the presence of integrated thinking, and whether HEI-specific characteristics could potentially influence the level of disclosure on IR content elements. The reason for focusing on IR content elements is to provide the most 
consistent and relevant framework for assessing the degree to which IR is being adopted throughout the sector.

The current study addresses several of the limitations of previous studies. First, this paper arises from prior researchers' suggestions for carrying out more research on IR due to the relatively new development in integrated reporting (Perego et al., 2016; Burke and Clark, 2016; Humphrey et al., 2016). Second, previous IR studies have been carried out in various sectors but few have been carried out in the higher education sector. For example, McNally and Maroun, (2018) carried out their investigation on the Ecotourism industry in South Africa. Feng et al., (2017) analysed professional accountancy bodies and accountancy firms in Australia. Kurochkina et al., (2017) examined transport and communication companies in Russia. Melloni et al., (2017) and Gunarathe and Senaratne, (2017) investigated IR in other sectors such as oil and gas, basic materials, industrials, consumer goods, healthcare, consumer service, telecommunications, utilities, financials, hotels and plantation service. Lueg et al, (2016) investigated IR in the context of family-owned businesses in Denmark. Third, our study is a response to the call from Adams, (2018) for a debate concerning IR adoption in HEIs in the UK as there are few prior IR studies in the HEIs and these studies have primarily been carried out in other countries. For example, Veltri and Silvestri, (2015) investigated IR in Free State University in South Africa. Chatelain-Ponroy and Morin-Delerm, (2016) in France, Nomura and Abe, 2010 (Japan), Lozano, 2011 (UK), Krizek et al., 2012 (USA), HEIs intellectual capital disclosure (Low et al., 2015 (New Zealand, Australia and UK), Bezhani, 2010 (UK), Sánchez et al., 2009 (Spain), Di Berardino and Corsi, 2018 (Italy), HEIs CSR disclosure (Maingot and Zeghal, 2008 (Canada), Larrán Jorge and Andrades Peña, 2014 (Spain). Fourth, from the IR framework implementation perspective, the research meets the call for more research on the disclosure of content elements (Melloni et al., 2015; Rowbottom and Locke, 2015; Lozano and Tirado-Valencia, 2016). This study uses the content elements 
framework to investigate the level of disclosure on IR in HEIs and examines whether HEIspecific characteristics allows for comparability in evaluating changes in reporting over the years. Furthermore, by including all of the IR content elements this study extends the BUDFG (2016) report which examined the presence of IR content elements in the annual reports of seven UK HEIs. Finally, this study also examines the implication of integrated thinking in HEIs when investigating the level of disclosure on IR content elements in UK HEIs as suggested by Adams (2017). If integrated thinking is having an impact on the UK HEI culture, it should affect the level of disclosure of information presented in the key strategy document - the annual report. Specifically, it should be possible to identify information that provides evidence that integrated thinking is taking place. One way of assessing this is to identify information corresponding to the IR content elements. The design decision was therefore made to examine the annual reports themselves rather than examining additional sources of information in sustainability reports and information from websites. In doing so, our study follows the approach of the BUDFG (2016) study. A further reason for not including information from HEI websites is that it tends to be replaced at regular intervals and thus does not lend itself well to a longitudinal study where IR disclosure developments from the key permanent document, the annual report or review, can be measured over years. The HEIs selected for this study are situated in the UK and the content analysis is based on annual reports published between 2014 and 2016.

This paper will proceed as follows: the next section will explain the theoretical framework and the following section will outline prior research and develop the hypotheses. The paper then turns to the methods and empirical findings derived from comparative analysis of HEI annual reports. The results based on the theoretical framework used are discussed and the finally the paper draws conclusions from the researchand provides recommendations for future research. 


\section{Theoretical Framework}

When investigating voluntary non-financial information disclosures, the theories widely used to understand the practices observed are institutional theory and legitimacy theory (Adams $e t$ al., 2016; Zappettini and Unerman, 2016; Ntim et al., 2017). Institutional theory has been useful in the general understanding of various accounting frameworks, approaches and techniques adopted by corporations, particularly in firm-specific and industry contexts (Adams et al., 2016). It explains how corporations adopt similar practices and structures to appease external expectations and gain legitimacy (Elmaghrabi, 2014). The assumption made under this theory is that organisations that adopt the new structure, framework or standard are more likely to gain external approval and this provides a relative balance in terms of the costs and benefits derived (Clegg and Hardy, 2005). Higgins et al., (2014) apply this to IR and suggest that an argument exists for IR adoption whereby the first adopter of IR would become "an organisational role model" and they suggest that this is crucial to IR adoption at a national level.

This research uses insights from institutional theory to investigate the level of disclosure on IR content elements in HEIs as given by the IIRC. This research also examines how institutional isomorphis $m$ and isopraxism interact in the reporting environment under the dynamics of conversion to an IR framework (Adams et al., 2016). Institutional isomorphism is the process by which organisations tend to adopt similar practices or structures over time in response to common institutional pressure which may exist at the organisational and/or industry level (Carpenter and Feroz, 2001). Coercive isomorphism is defined as a response to a legitimacy problem which requires organisations to conform to societal expectations including government regulations, new accounting standards, local authorities and central governments (Khadaroo, 2005). Normative isomorphism is akin to coercive isomorphism, although it is expressed through the concept of professionalisation, such as the requirement for 
membership of a professional body or through the formal educational process (Khadaroo, 2005).

Isopraxism, on the other hand, occurs when new ideas are accepted by corporations in similar or different situations, and explains why there are disparities between the practices adopted (Adams et al., 2016). In the higher education context, for example, these variations in adopted practices are a result of isomorphism whereby HEIs emulate one another regardless of the different structures of the higher education systems, student mobility and quality assurance convergence between national higher education systems (Hinson et al., 2015). The concepts of isomorphism and isopraxism are considered relevant for exploring the reasons why UK HEIs may or may not disclose all IR content in their annual reports. Isomorphism explains why the initial reporting structure and content are similar within the HEI sector, whereas isopraxism explains the disparities between reporting practices and could assist in the institutionalisation of a more integrated approach. This is a significant contribution to IR literature as the findings of this research indicate that the annual reports provided by UK HEIs are not all presently utilising the opportunity afforded by the IR framework (see Figure 1 for more details).

\section{Insert Figure 1 around here}




\subsection{Integrated thinking}

Integrated thinking is defined as "the reflection of connectivity and interdependencies between various factors which affect an organisation`s value creation capacity" (King IV, 2016 p. 13). According to the IIRC, integrated thinking should be embedded within an organisation`s activities, management reporting, decision making and includes the integration of internal and external reporting (IIRC, 2013 p. 2). In the business leadership literature, Martin and Austen, (1999) introduced integrated thinking as a problem-solving tool for managers within a complex and uncertain environment. Oliver et al. (2016) provide evidence that integrated thinking is significantly related to the results of environmental reporting. This implies that IR is dependent upon integrated thinking, whereby integrated thinking is implemented to provide a benchmark and as a means of achieving real integration in reporting (Adams, 2015). Therefore, integrated thinking should be embedded within organisational strategy, risk and opportunity identification processes, performance, sustainable development and outcomes (King IV, 2016). The IIRC IR framework provides the conceptual rigour required to support integrated thinking by adopting multiple capital approaches emphasised on connectivity with the corporate board and external environment to create value for short, medium and long-term outcomes (Adams, 2015).

However, Katsikas et al., (2016) explain that to adopt IR in practice, it is necessary to develop integrated thinking inside the organisation. This should institutionalise the integrated thinking process within the organisation and the related disclosures should be the final step towards IR. Adams (2017) provides clarity by providing the order of steps involved on the path towards integrated thinking and IR as follows: developing an understanding of sustainable development issues within the organisations external environment; identifying material sustainability issues; developing a business model to connect strategy and sustainability; developing integrated thinking, connectivity and governance; and preparing the integrated report. The International Federation of Accountants (IFAC, 2017) suggests that integrated 
thinking enables value creation within organisations and argues that integrated thinking is crucial for a better understanding of key organisational elements, different resources consumed, external environment, financial and other capitals, value for the organisation, value for others and internal factors. Therefore, if the culture which encourages integrated thinking is permeating the UK HEI sector, this should be evidenced across the sector over time in the content of their key strategic documents. By analysing the range of content in annual reports, this research examines to what extent UK HEIs demonstrate integrated thinking by investigating the level of disclosure of IR content elements in UK HEIs. The investigation also considers the reasons for potential disparities in the disclosures of HEIs and argues that integrated thinking is a new concept for reporting which must be taken into consideration alongside the following framework based on HEI specific characteristics. This is exemplified in Figure 2.

\section{Insert Figure 2 around here}

The IIRC (2013) asserts that integrated thinking can support integrated decision making and actions for short, medium and long-term value creation by making an active relationship between different operating and functional units, including multiple capitals. However, Veltri and Silvestri (2015) provide evidence from South African HEIs suggesting that IR has instead been used as a communication tool, which is issued to enhance university reputation and found no evidence of enhanced university stakeholder engagement. By investigating the level of disclosure on IR content elements in UK HEIs, this study contributes to the academic debate exploring the IR implications in the UK HEI sector in the context of the research of prior

scholars (De Villiers etal., 2014; Cheng etal., 2014; Veltri and Silvestri, 2015, BUFDG, 2016). 


\section{Literature review and development of hypotheses}

\subsection{Conceptual studies}

Conceptual studies attempt to generalise IR research and build up a conceptual foundation for further academic studies (De Villiers et al., 2014; Cheng et al., 2014; Adams, 2015). IR is described in conceptual studies as a "paradigm shift" in reporting practice (Adams, 2015). However, some scholars criticise the originality of IR and argue that the focus of disclosures should be on the accountability for financial investors rather than value for society. The IR framework is not a mandatory requirement in any country except South Africa (Flower, 2015) and, as such, a crucial concern for academic researchers is why corporations are adopting IR voluntarily. UK organisations are moving towards more transparent and embedded nonfinancial information in corporate reports despite a lack of legislation or regulation commanding them to do so (King III, 2009). This research contributes to the debate surrounding the voluntary adoption of IR, particularly considering the investigation of the level of disclosure on IR content elements in UK HEIs which implies an integrated thinking approach to governance, business model, measurement and reporting systems (Bousco et al., 2013; Adams, 2017).

Conceptually, IR is suggested to be a move away from narrow reporting towards a more consistent concept of an inclusive sustainable capital market system, organisational operating system and the evolution of integrated thinking (King IV, 2016). Integrated thinking, it has been argued, leads to integrated decision-making and actions for short, medium and long-term whereby value creation considers all capitals, organisational activities oriented towards stakeholder needs and interests including business models (IIRC, 2013). IR gives organisations the opportunity to increase their legitimacy and trust from stakeholders; manage risk and opportunity holistically; and portray their fundamental values and governance (King III, 2009). By developing the concept of integrated thinkin, as a precursor for IR, this study contributes 
towards bridging the gap in the literature concerning integrated thinking and IR within UK HEIs by following the integrated thinking steps suggested by Adams, (2017) when developing the disclosure index.

\subsection{Empirical studies}

There are few empirical studies that investigate IR in practice (Solomon and Maroun, 2012; Frias-Aceituno et al., 2013; Stubbs and Higgins, 2014; Lozano and Tirado-Valencia, 2016; Maroun, 2018). Other empirical studies have been based on interviews and surveys with early IR adopters (Stubbs and Higgins, 2014; Wee et al., 2016; Gunarathe and Senaratne, 2017). The findings of the research previously conducted indicates that early stage adopters of IR increase the quantitative reporting of risk management, internal control, social and environmental information (Solomon and Maroun, 2012), and feature qualitative forward-looking disclosures rather than purely quantitative reporting (Kilic and Kuzey, 2018). However, data outlook orientation, the interconnection of information and stakeholders' relationship for value creation are all identified as lacking in HEI reporting practice (Veltri and Silvestri, 2015).

Some scholars have raised concerns about IR literature regarding the concept of integrated thinking and its practical implications (Feng et al., 2017). From a practical perspective, it is argued that organisations should consider integrated thinking as an input into the business model and the resulting output, the outcomes of the organisation`s products and services, should include disclosures of the positive and negative impacts upon society and the environment (King IV, 2016). In terms of HEIs, the implication of integrated thinking is not known to have been studied by prior scholars. This study contributes to the literature by examining the implication of integrated thinking in HEIs when investigating the level of disclosure on IR content elements in UK HEIs. 
IR offers an opportunity for universities to develop their annual reports into engaging information for their stakeholders (BUFDG, 2016). However, in the higher education sector, sustainability assessments and communication are still in very early stages in terms of the number of institutions reporting and in the level of the discussion of sustainability issues. A number of studies have examined disclosure in the HEI sector. Gallego-Alvarez et al. (2011) analysed information disclosed online in Spanish HEIs in July 2008, whereas the present study focuses on investigating the level of disclosure of IR content elements in HEIs and whether HEIs specific characteristics could potentially influence the level of disclosure on IR content elements. The current study examines the extent to which the IIRC guidelines on integrated reporting are causing changes in disclosure over time in the key source of information that is available over time - the annual report. Lozano (2011) studied 12 individual reports between 2002 and 2008 from universities worldwide whereas the present study examines a much broader sample of 135 UK HEIs over time. Abed et al. (2016) analysed forward-looking information in UK companies, but focus on reports prior to the 2008 financial crisis. Low et al. (2015) examined voluntary reporting of intellectual capital (IC) by comparing the quality of disclosures from New Zealand, Australian and 44 United Kingdom universities. Likewise, Sangiorgi and Siboni (2017) examined disclosure of IC in Italian universities using 20 sustainability reports from 2013 and a survey. However, by using an index based on the IIRC guidelines, this analysis includes a broader range of university activities in addition to the creation of intellectual capital. Ntim et al. (2017) have a different focus in that they examine the relationship between governance and UK HEIs in a cross-sectional study using a public accountability and transparency index and data from 2012. Thus, our study contributes to the current IR research, where empirical findings are rare, by improving current knowledge and understanding of the motives and level of disclosure of IR content in UK HEIs.

\subsection{Literature review and development of hypotheses}


A review of the prior literature concerning IR information disclosures of HEI core activities (including teaching and learning, research and internationalisation as disclosure) reveals that IR significantly affects HEI reputation, performance and stakeholder relationships. In addition to the HEI sector-specific characteristics, corporate governance variables have been extensive in prior disclosure literature. However, IR content element disclosure and HEI core activity disclosure can be influenced by many factors. This study examines the HEI specific characteristics that could potentially influence the level of IR content elements disclosure in HEIs annual reports. The four HEI specific characteristics are the following: period of establishment of the HEI; IR adoption; performance position ranking in the league table; and governing board size.

\subsubsection{Establishment of HEIs}

In 1992 the UK government formally abolished the binary divide between universities and polytechnics to establish a unitary system of higher education for the UK (Boliver, 2015). The 1992 Further and Higher Education Act granted 35 polytechnics full university status, thereby increasing the number of universities by $50 \%$ and doubling the number of university students virtually overnight (Halsey, 2000). However, these developments did not change the fact that old, pre-1992, universities continued to be held in higher regard than new, post-1992, universities and that differences in esteem were prevalent even amongst the old universities (Scott, 1995). Previous studies of the establishment of universities classified UK universities into two main groups: universities established pre-1992 (old universities) and universities established post-1992 (new universities) (e.g. Asaad et al., 2013; Maringe, 2009; Lomas, 2006; Ntim et al., 2017). These studies found that pre-1992 HEIs disclose significantly more financial and research information than their post-1992 counterparts, but there are no significant differences between pre- and post-1992 institutions regarding the overall disclosure level. However, Asaad et al., (2013) discovered that post-1992 universities have a high volume of 
teaching income that includes income from international students. This suggests that post-1992 universities have the biggest increase in diversity of student ethnic background.

Maringe (2009) finds that pre-1992 universities are prominent in research, but that post-1992 universities can also be considered beneficial as they increase organisational competitiveness by attracting more international students and international staff. Further, Lomas (2006) argues that post-1992 universities improve the quality of teaching and learning, including success in the Virtual Learning Environment (VLE). The VLE lead rate is around 80 percent and this demonstrates the importance of the culture in post-1992 universities that allows them to flourish despite a lack of established research culture and limited research funding. Prior studies indicate that post-1992 universities are also more open towards improving the quality of teaching and learning, internationalisation and adoption of modern technology for teaching and communication. This suggests that post-1992 universities can benefit significantly if they can create an engaging narrative for overseas students by disclosing across a full range of information across all of the content elements. However, it is expected that more established universities are still in a stronger position when it comes to disclosure. Although post-1992 universities are increasing the disclosure of their activities and the gap between the two groups may be closing, they may still be in the process of realising the advantages of disclosing across the wide range of their activities, and furthermore, are able to devote less time and resources than pre-1992 universities to assembling the content required to create this narrative. To the best of our knowledge, this is the first study to examine the impact of the period of establishment of HEIs on the disclosure level of integrated reporting. Based on the above discussion, the present study investigates whether the period of establishment of the HEI (before or after 1992) has an effect on the level of disclosure of the integrated reporting content elements. This leads to the first hypothesis of the current study: 
H1. Older established universities (pre-1992) are more likely to provide disclosure on IR content elements than newly established universities (post-1992).

\subsubsection{IR adoption}

Prior studies of Corporate Social Responsibility (CSR) voluntary disclosure have used the Global Reporting Initiative (GRI) framework adoption as an independent variable to measure the level of disclosure on CSR reporting. For example, Hassan et al., 2013 and Elmaghrabi, 2014 examined GRI application relation to voluntary disclosure and concluded that a higher GRI application level tends to be associated with better sustainability embeddedness in corporate reporting. Prior studies of IR that have implemented the same approach by including IR adoption as one of IR research variables have provided mixed results. Some previous studie s found that IR adoption is highly positively associated with accounting disclosure and nonfinancial information disclosure (Pavlopoulos et al., 2017; BUFDG, 2016; Haji and Anifowose, 2017). Other studies reported that IR adoption has no effect on disclosure: for example, Stubbs and Higgins, (2014) concluded that early IR adoptors in Australia did not change their reporting structure radically. Haji and Anifowose, (2016) found that early examples of IR in South Africa omitted the connectivity of information, reliability, completeness and trade-off between various capitals. The present study joins this debate to explore whether there is a relation between the adoption of integrated reporting and an increased reporting on the specific content elements, suggesting that integrated thinking is present. If there is a stated adoption of integrated reporting but no corresponding increase in reporting of the content elements, it would suggest that a decoupling is taking place between the stated adoption of IR and the process of integrated thinking with its resulting wide range of disclosure and interconnection. BUFDG (2016) have provided evidence that UK universities are beginning to demonstrate some of the concepts of integrated reporting and include relevant content elements but that more practice is needed in critical analysis and creativity to draw out the narrative from the 
figures and tell their stories. Therefore, it is expected that IR adoption will exercise a positive influence on the level of IR content elements disclosure including teaching and learning, research and internationalisation disclosure is expected. Hence, the second hypothesis:

H2. There is a positive relationship between university adoption of IR and the level of disclosure on IR content elements.

\subsubsection{League table performance}

Gibbons et al., (2015) define university league tables as a type of organisational report card that provides explicit organisational rankings. According to Berbegal-Mirabent and RibeiroSoriano, (2015) university ranking has become important for public accountability. These rankings supply information on the measurable dimension of service quality and encourage institutional transparency including stimulating a culture of quality assessment in education. Furthermore, Gibbons et al., (2015) have demonstrated that the National Student Survey has a statistically significant impact on student applications. The influence of these satisfaction ratings is primarily exerted through league tables because candidates of high ability are more responsive to league tables and changes in rankings have a measurable impact on student decisions. Christie (2016) also provides evidence showing the significance of the league table in contributing to establishing a trustworthy status, employment measurement and comparisons with other stakeholders. The Guardian League Table (2017) indicators are the following: satisfaction with course, satisfaction with teaching, satisfaction with feedback, student allocation, student spending allocation and average entry tariff. It has been argued that league table ranking is perceived as a reflection of the quality of education because when the result of a ranking is positive, universities are quick to post the ranking in their website (Broecke, 2015). However, in terms of new entrant, the information disclosed by the universities are not useful in taking decision about the university (Dilnot, 2018). Therefore, we would expect that there is a link between the performance of HEIs and the level of disclosure provided of IR content 
elements. HEIs which adopt an integrated thinking approach and provide disclosure of IR content elements will be able to operate more efficiently and communicate their unique value to students more effectively, and that this will have a positive impact on student engagement and rankings. This leads to our third hypothesis:

H3. There is a positive relationship between university performance position ranking in league tables and the level of disclosure on IR content elements.

\subsubsection{University governing board size}

Prior scholars provide inconsistent evidence about the relationship between governing board size and the level of voluntary disclosure. For example, Cheng and Courtenay, (2006) and Haniffa and Hudaib, (2006) concluded that there is no significant relationship between size of governing board and voluntary disclosure and performance of publicly listed corporations. However, Yafele, (2012) found a statistically significant association between governing board size and voluntary key performance indicator (KPIs) disclosure. Studies in the higher education sector have found a statistically insignificant relationship between governing board size and level of voluntary disclosure (Gallego - Alvarez et al., 2011; Ntim et al., 2017). The present study investigates whether there is any significant relationship between providing disclosure of IR content element and university governing board. Our study examines the level of disclosure on IR content elements which has not previously been examined. Based on the above mixed results, we hypothesise that governing board size will be related to IR, however, we do not stipulate the coefficient direction:

H4. There is a significant relationship between university governing board size and the level of disclosure on IR content elements. 


\section{Methodology}

\subsection{Sample selection}

The sample comprises a population of 135 UK HEIs. The list of HEIs was taken from the Complete University Guide (2017) for academic years 2013/14, 2014/15 and 2015/16 respectively. These years were selected as the IIRC issued their new guidelines about IR content elements in 2013 and thus the study examines whether there are any subsequent improvements in the level of disclosure of IR content elements. This study covers a broader sample of the annual reports prepared by HEIs located in England, Scotland, Northern Ireland and Wales in comparison to prior studies. The study of Ntim et al., (2017) was based on corporate governance and voluntary disclosure about 130 UK HEIs with the size of $£ 5$ m annual income for 2012. Lozano, (2010) studied 12 universities worldwide for sustainability disclosure analysis and Maringe (2009) developed results based on internationalization disclosure by investigating 6 UK HEIs that were listed as Russell Group and only post-1992 establishments. This study collects different types of secondary data related to HEI sectorspecific characteristics and IR content elements disclosure. The IR content elements were based on the IR framework published by the IIRC, (2013). The control variables used for this study involved the selection of a sample of financial variables, which were downloaded primarily from HEI annual reports, HEI websites and other publicly available information.

\subsection{Research variables}

Integrated Reporting disclosure index (dependent variable). This study adheres to the techniques of prior literature on HEIs and employs content analysis. The concept of content analysis is to obtain the data through a process of observation and analysis of the content or message of written texts. Content analysis is often used to study information provided by profitoriented and non-profit organisations (Garanina and Dumay, 2016; Gallego-Alvarez, et al., 2011) and is used in research for making replicable and valid inferences from texts to the 
contexts of their use (Krippendorff, 2004). Content analysis is widely used in business corporation disclosure analysis (Ahmed Haji \& Anifowose, (2017); Gunarathe and Senaratne, (2017). In the HEI sector, prior scholars have frequently used content analysis to examine the disclosures of universities in Spain (Gallego-Alvarez et al., 2011) and in the UK (Ayoubi and Massoud, 2007; Jiang and Carpenter, 2013; and Low et al., 2015). The current study follows this practice to analyse voluntary disclosure in the UK HEI sector.

To construct the disclosure index, the researchers followed the IR framework provided by the IIRC (2013) and recently adopted by the BUFDG (2016) and focused only on the integrated reporting content elements. According to the IIRC, an integrated report includes eight content elements which are as follows: organisational overview and external environment, governance, business model, risk and opportunities, strategy and resource allocation, performance, outlook and basis of preparation and presentation (IIRC, 2013). The IR content elements for the disclosure index are developed on the basis of the IR framework 2013. However, some of the disclosure items are influenced from prior studies, such as financial information, corporate governance, strategic planning and sustainability-related items based on (Gallego-Alvarez et al., 2011; Ntim et al., 2017); non-financial performance, strategy and different capitals items linked with (Sangiorgi and Siboni, 2017; Low et al., 2015); environmental indicators, strategic management and stakeholders' engagement items based on (Lozano, 2011; Abed et al., 2016). A pilot study was conducted and examined six HEIs including their annual reports. Three coders from three different universities worked independently to code the HEI annual reports. The three coders then had a meeting to discuss and reconcile any differences. Feedback provided by the coders led to a revision of the disclosure index. (See Appendix 1 for the disclosure index).

This research adopted the weighted scoring method for disclosure indices and this assigns a weight to each item to consider the variation in the importance of each type of 
information (Cheunge et al., 2010). This is important as a disclosure index that remains unweighted analyses whether disclosure indices items are disclosed or not but does not consider and measure the extent of disclosure items (Alsaeed, 2006). This research provides depth to the findings by use of weighted indexes which deliver detailed provision of qualitative and quantitative ranges of data. To weight the disclosure index, the researchers followed prior studies: Adams (2017) who argues that integrated thinking is the connection of value creation model with strategy and governance; IIRC (2013) in which integrated thinking links the information on risk and opportunity, strategy and resource allocation, performance and future outlooks; and Al - Htaybat and Alberti-Alhtaybat, (2018) who argue that IR is the results of the growth of integrated thinking approach over the time and its reflection. The researchers compared the eight themes with strategy, governance, performance and prospects, linked with past and future prospects and HEIs that linked all themes scored higher in the disclosure index which reflects a greater commitment to integrated thinking by the HEI. The index structured as follows: no disclosure $=0$, descriptive disclosure without any link to strategy, governance, performance and prospect=1, descriptive disclosure and link with all strategy, governance, performance and prospect compare with historic position $=2$, descriptive disclosure linked with all strategy, governance, performance and prospect compare with historic, present and future position $=3$. The total disclosure score of IR content elements disclosed in HEI annual reports integrated reporting score is the dependent variable.

Independent variables. The researchers also collected data on (1) HEI sector-specific characteristics includes period of establishment of the HEI (EST) (Ntim et al., 2017; GallegoAlvarez, et al., 2011); (2) IR framework adoption (IRDP) (Gunarathe and Senarathe, 2017; Solomon and Maroun, 2012); (3) league table position ranking (LTR) from Guardian League table of 2017 (Christie, 2016); and (4) the number of members in the governing board (BSIZE) (Ntim et al., 2017; Gallego-Alvarez, et al., 2011). 
Control variables. (1)Size- Earlier studies provide evidence that there is a positive association between corporation size and voluntary disclosure in public listed companies (Lang and Lundholm, 1993; Yafele, 2012). However, Bukh et al., (2005) did not find that company size had a role in explaining voluntary disclosure. Studies in higher education have also found that the size of the university is statistically positively associated with voluntary disclosure (Maingot \& Zeghal, 2008 (Canada); Gallego-Alvarez et al., 2011 (Spain). (2) GrowthMohamed, (2015) found no relationship between growth and voluntary disclosure. Ntim et al., (2017), on the other hand, found that faster growing universities tend to do provide less voluntary information disclosure. (3) Liquidity- Yafele, (2012) found that liquidity has a weak association with voluntary KPI disclosure for publicly listed companies. In contrast, Cooke, (1998) argued that high liquidity of the firm tends to correspond to a higher level of voluntary disclosure. However, in the higher education sector, research has not shown a significant relationship between liquidity and the level of voluntary disclosure (Ntim et al., 2017). (4) Funding- Gordon et al., (2002) found that corporations with higher public funding tend to have higher levels of disclosure. Likewise, Ntim et al., (2017) concluded that HEIs with higher funding levels disclose more voluntary information. (5) Total Endowment Assets- (TEA) Ntim et al., (2017) found no link between HEI voluntary disclosure and TEA. (Ntim et al., 2017). However, it could be expected that those HEIs with large endowment assets will also provide more disclosure on IR content elements. This variable was therefore included to either support or contradict prior literature.

Due to the cross-sectional nature of the data collected, the empirical analysis commences with descriptive statistics, correlation and regression analysis (see Table 1 for the measurement of the research variables). Table 1 classifies the research variables used in $H 1-$ $H 4$ for three years 2013/14, 2014/15, 2015/16 and explains the variables measurement process. 


\section{Insert Table 1 around here}

\subsection{Data analysis and model specification}

Data analysis proceeds in five steps. Firstly, descriptive statistics of all study variables are calculated, including mean, standard deviation, minimum, maximum, and quartile. Secondly, the total integrated reporting content elements' disclosure score for research sample is presented. Thirdly, t-test and chi-square tests are conducted to explore as sociations between integrated reporting content elements and establishments of higher education institutions. Fourthly, Pearson correlation coefficients are calculated between the study variables. Finally, hypothesis testing is conducted via ordered logistic regression to estimate the influence of explanatory variables on providing disclosure on the content elements of the integrated reporting. Generally, logistic regression is well suited for describing and testing hypotheses about relationships between a categorical outcome variable and one or more categorical or continuous predictor variables (Liao et al. 2017; Menard, 2018).

The regression model is specified as:

$$
\begin{aligned}
& \text { TOTAL }_{i t}=\beta_{0}+\beta_{1} E S T_{i t}+\beta_{2} I R D P_{i t}+\beta_{3} L T R_{i t}+\beta_{4} S I Z E_{i t}+\beta_{5} B S I Z E_{i t}+ \\
& \beta_{6} G R O W T H_{i t}+\beta_{7} F U N D_{i t}+\beta_{8} L I Q D_{i t}+\beta_{9} T E A_{i t}+\varepsilon_{i t}
\end{aligned}
$$

where TOTAL is total IR content elements disclosure score; EST refers to establishment of HEI (before or after 1992); IRDP refers to the IR framework adoption; LTR refers to performance position ranking in the league table; BSIZE refers to number of members in HEI governing board and control variables of total assets depicted as SIZE; percentage of current periods total income minus previous periods total income to previous periods total income is given as GROWTH; percentage of total annual council funding income to total annual income is referred 
to as FUND; current assets divided by current liabilities is $L I Q D$; and the percentage of total annual endowment assets to total annual assets is TEA.

\section{Results and Discussion}

\subsection{Descriptive statistics}

Table 2 presents the summary of descriptive statistics for all dependent variables, independent variables and control variables. It also presents the statistics of the eight themes of IR content elements. Evaluation of the summary's descriptive statistics indicates rather important findings. There was a large degree of variability in the summary of IR content elements disclosure in the HEI sector which aligns with the findings of prior studies (Coy and Dixon, 2004; Gallego-Alvarez et al., 2011; Ntim et al., 2017). The scores range from a minimum of 0 to a maximum of 19 in some themes and ranges from a minimum of 29 to a maximum of $108 / 168$ for the total IR content elements scores and a widespread distribution is depicted in Table 2. Total disclosure relating to the league table ranking position (LTR) intervals range from a minimum of 0 to maximum of 126 and total disclosure related to HEI governing board size (BSIZE) reveals from a minimum of 10 to maximum of 45 . The overall measure of IR content elements disclosure ranged between $47.47 \%$ in $2013 / 14$ to $67.9 \%$ in $2015 / 16$ which indicates an improvement in the level of disclosure on IR content elements. This can be interpreted as reflecting an increasing awareness of IR in general and disclosure of IR content elements in particular. This result is higher than the Ntim et al., (2017) who found a score of $44.02 \%$ when measuring the voluntary disclosure in 130 UK HEIs in 2012. It is comparable with studies from some universities around the world, e.g. Spanish universities scored $56.9 \%$ (Gallego-Alvarez et al., 2011)

Insert Table 2 around here 


\subsection{Analysis of integrated reporting content elements disclosure index}

Two different types of analysis were carried out to present the integrated reporting content elements disclosure index. First, the total scores over the selected three years of the study (2013/14, 2014/15 and 2015/16) for all universities in our sample (See Table 3). The results show that there is an increase in the level of disclosure on integrated reporting content elements provided by our sample over the years. For example, the average HEI disclosed 47 (27.98\%), $58(34.52 \%)$, and $68(40.48 \%)$ disclosure index score in 2013/14, 2014/15 and 2015/16, respectively, accounting for over $44 \%$ increase over the three-year period investigated. This seems to suggest that UK HEIs attach some importance to integrated reporting. Second, similar increasing patterns can be observed with respect to the 8 integrated reporting thematic areas. For instance, $O E E$ disclosures are between 4(19.05\%) and 19(90.48\%) with an average of 9.86 (46.95\%) disclosure index score and increasing steadily from $8.40(40 \%)$ in $2013 / 14$ to 11.27(53.67\%) in 2015/16. The pattern of increases in GVN, VCM, RO, SRA, PM, OLK and $B P P$ are similar to those of $O E E$. Third, and on a comparative basis, disclosure levels are highest in the case of $O E E$ and least with respect to $O L K$. This is not surprising since unlike the $O E E$, which contain general information about organisational overview and external environment, the $O L K$ scope is more specific predictions, covering 7 disclosure items ranging from issues, such as institutional expected external environment (IEEE) to interrelationship between institution`s objectives, external source and any forecast or assumption if any (IOEA). We interpret the increase in the level of disclosure of IR content elements as an evidence of the institutionalisation of the integrated thinking process with UK HEI (Katsikas et al., (2016). In addition, our results support the prior study of Adams (2017) in identifying the order of steps involved on the path of integrated thinking. Our disclosure index items included most (if not all) of the integrated thinking steps suggested by Adams (2017). These items are Organisational Overview and External Environment (OEE, Governance (GVN), Value Creation Model - 
Business Model (VCM), Risk and Opportunity (RO), Strategy and Resource Allocation (SRA), Performance (PM), Outlook (OLK), Basis of Preparation and Presentation (BPP). Our results also support the theory of coercive isomorphis $m$ as we can see the disclosure on IR content element as a response to IIRC Guidelines which require organisations to conform to societal expectations including government regulations (Khadaroo, 2005; Adams et al., 2016).

Table 3 shows similar increasing patterns with respect to integrated reporting content elements in both pre and post-1992 institutions. However, pre-1992 HEIs provide slightly higher disclosure on integrated reporting content elements. For example, and consistent with the general increasing pattern in integrated reporting content elements behaviour over-time, the average pre-1992 HEIs scored 29.04\% (48.79 sentences) of the total of 168 disclosure points in $2013 / 14$ compared with $35.38 \%$ (59.43 sentences), and $41.36 \%$ (69.48 sentences) in 2014/15 and 2015/16, respectively. In addition, the eight sub-themes illustrate mostly similar integrated reporting content elements behaviour over time.

\section{Insert Table 3 around here}

The investigators ran t-test and Mann-Whitney $U$ tests to investigate if there are any differences in the level of disclosure of integrated reporting content elements and the date of establishment (EST) of the higher education institutions (pre and post-1992). Table 4 presents the totals of the eight themes (Organisational Overview and External Environment (OEE); Governance (GVN); Value Creation Model (VCM); Risk and Opportunity (RO); Strategy and Resource Allocation (SRA); Performance (PM); (7) Outlooks (OLK) and Basis of Preparation and Presentation (BPP). This is based on the assumption that the total of each theme is enough to explain the results. However, a full analysis of t-test and Mann-Whitney U tests of all the disclosure items of our index is available upon request. These findings indicate that, in general, pre-1992 HEIs provide more disclosure on integrated reporting content elements. T-test test identifies significant differences (t-test $\mathrm{p}=.074$ ) between pre and post-1992 institutions with 
regard to most of 7 items. For example, OEE (t-test $p=.017$ and Mann-Whitney $p=.037$ ). Collectively, the above findings indicate that pre-1992 HEIs provide higher levels of disclosure than their post-1992 counterparts. This supports H1: Older established universities (pre-1992) are more likely to provide disclosure on IR content elements disclosure than newly established universities (post-1992).

\section{Insert Table 4 around here}

\subsection{Correlation Matrix}

Table 5 presents the correlation matrix for the variables used in our regression analysis to test for multicollinearity and we also report the Pearson parametric coefficients. The results show that there is a significant positive relationship between the dependent variable (Total IR) and integrated reporting framework adoption IRADP (0.172). The results also show a positive but insignificant relationship between Total IR and league table ranking position HEI governing board size BSIZE (0.027) and a significant negative relationship with the HEI governing board size BSIZE (-0.003). In terms of the control variables, the results show no relationship between growth GWTH (-0.032), funding FUND (0.063) and Total endowment assets TEA (-0.048). However, there is a positive significant relationship between Total IR and HEI total assets SIZE (0.139). In addition, the correlations among the variables are relatively low, suggesting that there are no serious multicollinearity problems. Hair et al. (2013) show that high correlations (generally 0.90 and above) indicate the presence of severe multicollinearity problem.

\section{Insert Table 5 around here}

\subsection{Multivariate Results}

Table 6 presents the regression results for the relationship between Total IR and all research variables.

Establishment of HEI and Total IR disclosure. Model 1 of Table 6 shows that the date of establishment of HEI is positively and significantly associated with Total IR disclosure. This 
supports the argument that the HEIs established before 1992 have more IR content elements disclosure compared with the HEI established after 1992. Maringe, (2009) found that due to increasing competition and change in HEI funding since 2006, the pre-1992 universities in the UK changed the content of reporting to attract talented people from around the world. Ntim et al. (2017) found that the HEIs established before 1992 disclose significantly more financial and research information compared with the HEIs established after 1992. Therefore, the above results suggest that there is strong support for $H_{1}$ (Older established universities (pre-1992) are more likely to provide disclosure on IR contentelements than newly established universities (post-1992)).

Integrated reporting and thinking of pre-1992 universities, which may produce an efficient and productive capital allocation, may operate as a force for financial strength and sustainability. This implies that pre-1992 universities employ integrated reporting and thinking to gain powerful stakeholders such as alumni, Students Loans Company (SLC), prospective students and employers and new competitive and market environment (e.g. elimination of limits on the number of students that can be recruited by an HEI) support and expectations.

\section{Integrated reporting framework adoption and Total IR disclosure framework. Model} 1 of Table 6 also displays the regression results for the relationship between the IR framework adoption $(I R A D P)$ and Total IR disclosure. Our results show that there is a positive relationship between integrated reporting framework adoption (IRADP) and Total IR disclosure $(t=4.57)$. This result is in line with numerous prior studies which find a positive relationship between integrated reporting framework adoption and Total IR disclosure (Solomon and Maroun, 2012; Melloni et al., 2017; Pavlopoulos et al., 2017). Additionally, Feng et al., (2017) suggested that the integrated reporting framework is significantly well developed to drive organisational reflection or reporting and attract wider corporate engagement. This provides support for $\mathrm{H}_{2}$ : (There is a positive relationship between university adoption of IR and the level of disclosure 
on IR content elements). This result supports previous research (Bebbington and Larrinaga, 2014; Bebbington and Thomson, 2007; Thomson et al., 2014) that sugge sts that HEIs that adopt IR may generate better visibility and knowledge of the financial values of exploiting capitals (financial, intellectual, human, manufactured, social, and natural) and offer a diverse lens to reassess aspects of HEI organisational performance that support the growth of integrated thinking.

\section{Insert Table 6 around here}

\section{University ranking and Total IR disclosure framework}

Model 1 of Table 6 shows that there is no significant relationship between university performance position ranking in league table $(L T R)$ and Total IR disclosure $(t=0.87)$. Our results are in line with prior studies, which find that the higher the position ranking in league tables, the higher the disclosure for performance, student satisfaction and graduate employment rate. The reason for the lack of a significant relationship may be found in the debate around the issue of university rankings, particularly for post-1992 universities. Maringe (2009) argues that for lower-ranked universities, the ranking of specific subject/school and other qualities can be a competitive advantage and can account for their scope internationally. The result for this sample of universities implies that there is no significant relationship between university ranking and level of disclosure on IR. Thus, we reject $H_{3}$ : (There is a positive relationship between university performance position ranking in league tables and the level of disclosure on IR content elements). This implies that an appropriate sector-wide enforcement and compliance body, for instance, the British Universities Finance Directors Group (BUFDG), may consider developing voluntary IR guidance in a clear, consistent, concise and comparable format. Also, it may pursue regulatory support for this guidance. In doing so, it may monitor the compliance and disclosure levels of appropriate IR requirements. By supporting this 
approach, IR can help HEIs to make more sustainable choices and allow stakeholders to understand how an HEI is actually performing.

\section{HEI governing board size and Total IR disclosure framework}

The findings of Model 1 of Table 6 indicate that there is a positive relationship between the number of members of the HEI`s governing board (BSIZE) and Total IR disclosure, however, this relationship is not significant statistically $(t=0.19)$. Prior studies have found no significant relationship between HEI governing board size and Total IR disclosure (Ntim et al., 2017; Gallego-Alvarez et al., 2011). Thus, $\mathrm{H}_{4}$ is rejected: (There is a significant relationship between university governing board size and the level of disclosure on IR content elements). This implies that further governance reforms may lead to greater demand for IR disclosure, public accountability and transparency, largely through improved external regulatory examination and funding environments.

\section{Additional Analyses}

In this section, we carry out a set of additional analyses that aim at determining the robustness of the main results from the previous section. First, we use random-effects regression analysis (Alnabsha et al., 2018; Elamer et al., 2017; Ntim et al., 2016) to investigate whether HEI specific features influence Integrated Reporting (IR) disclosure. Omitted variables are a probable source of endogeneity in our study context. HEIs with certain features could choose to disclose more information about Integrated Reporting. Reverse causality is another potential source of endogeneity. In that occasion, the OLS regression in Model 1 of Table 6 would be biased. To deal with endogeneity, we use a random-effects regression as follows:

$$
\begin{aligned}
& \text { TOTAL }_{i t}=\alpha_{0}+\beta_{1} E S T+\beta_{2} I R D P+\beta_{3} L T R+\beta_{4} \text { BSIZE }+\sum_{i=1}^{5} \beta_{i} \text { CONTROLS }_{i t}+ \\
& \delta_{i t}+\varepsilon_{i t}
\end{aligned}
$$


where TOTAL is total IR content elements disclosure score; EST refers to the establishment of the HEI (before or after 1992); IRDP refers to the IR framework adoption; LTR refers to performance position ranking in the league table; BSIZE refers to the number of members on the HEI governing board. CONTROLS refer to total assets depicted as SIZE; percentage of current periods total income minus previous periods total income to previous periods total income is given as GROWTH; percentage of total annual council funding income to total annual income is referred to as FUND; current assets divided by current liabilities is LIQD; and the percentage of total annual endowment assets to total annual assets is TEA. $\delta$ is the Universityyear specific effects, and $\varepsilon$ is the error term. The results are reported in Model 2 of Table 6 . These results are highly similar to those represented in Model 1 of Table 6, suggesting that our results seem to be robust to the potential endogeneities that may be affected by omitted variable bias or/and reverse causality.

Second, we further address potential endogeneities that may be affected by omitted variable bias by estimating using two-stage least squares (Elamer and Benyazid, 2018). In the first stage, based on extensive theoretical and empirical research (Larcker \& Rusticus, 2007, 2010; Ntim et al., 2017),we conjecture that board size (BSIZE) and HEI league table ranking (LTR) will be determined by all the control (exogenous) variables specified in equation (1). In the second stage, we employ the predicted values of the board size and HEI league table ranking as an instrument for board size and HEI league table ranking and re-estimate equation (2) as follows:

$$
\begin{aligned}
& \text { TOTAL }_{i t}=\alpha_{0}+\beta_{1} \text { EST }+\beta_{2} \text { IRDP }+\widehat{\beta}_{3} \text { LTR }+\widehat{\beta}_{4} \text { BSIZE }+\sum_{\mathrm{i}=1}^{5} \beta_{\mathrm{i}} \text { CONTROLS }_{\text {it }}+\delta_{\text {it }}+ \\
& \varepsilon_{\text {it }}
\end{aligned}
$$

where everything else remains unaffected as stated in equation (2) except that we use the instrumented part of the LTR and BSIZE. The results are reported in Model 3 of Table 6. These 
results are also similar to those presented in Model 1 of Table 6, indicating that our findings appear to be robust to potential endogeneity that may be caused by omitted variables bias.

Third, to ascertain the assumption underlying our OLS regression model that all the unobserved heterogeneities may affect the correlation between the governance variables and the error term is invariable over time, we calculate a lagged estimator as proposed by Ntim et al. (2016). The findings are reported in Model 4 of Table 6. Again, we find the results indicate a positive and statistically significant relationship among the EST, IRDP and TOTAL indices. These results are also largely similar to those reported in Model 1 of Table 6, and thereby implying that our results are not strongly affected by potential endogeneity problems that may be caused by simultaneity.

\section{Conclusions}

Over the past two decades, public organisations have started publishing voluntary reports (e.g. corporate social responsibility reports, sustainability reports and intellectual capital reports) to convey non-financial information to organisational stakeholders. However, these supplements have been criticised as being detached from the main corporate reports, overloaded with information and incurring excessive costs (Eccles and Krzus, 2010; Veltri and Silvestri, 2015; Wee et al., 2016). As a solution, integrated reporting (IR) has been developed to provide combined disclosure of financial, environmental, social and governance information instead of the separation of financial information from sustainability information. This is achieved by the publication of a single report from the perspective of stakeholders towards the organisation in society and sustainable development (King IV, 2016; Soh et al., 2015; Reimsbach et al., 2017).

By implementing IR, it is argued that organisations can "tell the story" of all the activities undertaken for value creation (King IV, 2016). Recognising and reporting multiple sources of capital, qualitative information about organisations` missions and forward-looking information 
on IR should be an attractive means to reflect value created for both profit-oriented and nonprofit organisations. The British Universities Finance Directors Group (BUFDG) report (2016) emphasises that Higher Education Institutions (HEIs) have an interesting story to tell their stakeholders about the importance of their role in sustainable value creation and IR helps them to tell that story. Universities have a unique place in society. They are not only centres of creative thinking and innovation but also fulfil many additional roles, providing leadership, advice and support. However, this varied contribution has often been little reflected in the communications between universities and wider society (BUFDG, 2016). This suggests that HEIs can benefit from being more transparent when disclosing value creation activities to their stakeholders using IR. Therefore, the main aim of this study is to investigate to what extent UK HEIs provide disclosure on IR content elements given by the IIRC, suggesting the presence of integrated thinking, and whether HEI-specific characteristics could potentially influence the level of disclosure on IR content elements.

The findings indicate that there is an overall trend towards increasing IR content elements disclosure. Analysis over the three financial periods 2013/14, 2014/15 and 2015/16 of UK HEIs showed an increase in the total level of IR disclosure from just over $47 \%$ to nearly $70 \%$, with a higher level of disclosure on IR specific content from pre-1992 universities. The increase in the level of disclosure on IR content elements can be seen as evidence of institutionalising the integrated thinking process with UK HEI (Katsikas et al., (2016). In addition, our results support the prior study of Adams (2017) in identifying the order of steps involved on the path of integrated thinking. Our results also support the theory of coercive isomorphism as we can see the disclosure on IR content element as a response to IIRC guidelines which require organisations to conform to societal expectations including government regulations (Khadaroo, 2005; Adams et al., 2016). 
Our results provide support for two hypotheses. Our results provide strong support for $H_{1}$ (Older established universities (pre-1992) are more likely to provide disclosure on IR content elements than newly established universities (post-1992). Integrated reporting and thinking of pre-1992 universities, which may produce an efficient and productive capital allocation, may operate as a force for financial strength and sustainability. This implies that pre-1992 universities employ integrated reporting and thinking to gain powerful stakeholders such as alumni, Students Loans Company (SLC), prospective students and employers and new competitive and market environment (e.g. elimination of limits on the number of students that can be recruited by an HEI) support and expectations. Our results also provide support for $\mathrm{H}_{2}$ : (There is a positive relationship between university adoption of IR and the level of disclosure on IR content elements). This result supports previous research (Bebbington and Larrinaga, 2014; Bebbington and Thomson, 2007; Thomson et al., 2014) that suggests that HEIs that adopt IR may generate better visibility and knowledge of the financial values of exploiting capitals (financial, intellectual, human, manufactured, social, and natural) and offer a diverse lens to reassess aspects of HEI organisational performance that support the growth of integrated thinking.

On the other hand, our results reject two hypotheses. The results did not support $H_{3}$ : (There is a positive relationship between university performance position ranking in league tables and the level of disclosure on IR content elements). This implies that an appropriate sector-wide enforcement and compliance body, for instance, the British Universities Finance Directors Group (BUFDG), may consider developing voluntary IR guidance in a clear, consistent, concise and comparable format. Also, it may pursue regulatory support for this guidance. In doing so, it may monitor the compliance and disclosure levels of appropriate IR requirements. By supporting this approach, IR can help HEIs to make more sustainable choices and allow stakeholders to understand how an HEI is actually performing. Our results related 
to $\mathrm{H}_{4}$ is also rejected: (There is a significant relationship between university governing board size and the level of disclosure on IR content elements). This implies that further governance reforms may lead to greater demand for IR disclosure, public accountability and transparency, largely through improved external regulatory examination and funding environments. We also carried out a set of additional analyses to determine the robustness of our results. The additional results suggesting that our results seem to be robust to the potential endogeneities that may be affected by omitted variable bias or/and reverse causality.

The findings appear to be comparable in comparison with other research results on voluntary disclosure in the UK HEI sector; 44.02\% from 130 UK HEIs in 2012 (Ntim et al., 2017); and 56.9\% from 78 Spanish HEIs (Gallego-Alvarez et al., 2011). Akin to the business organisational sector, the lack of IR content element disclosure could be due to the lack of expertise and/or lack of resources to produce an integrated report appropriately. This study focussed on HEI annual report disclosure which does not consider the possibility that HEIs perhaps rely more on other forms of public communication (website, press releases, social media). From a methodological point of view, the disclosure index was constructed based on the IR framework produced by the IIRC, (2013). However, the IR framework is in a period of infancy and still requires a lot of dialogue to support implementation in the HEI sector (Veltri and Silvestri, 2015). In the UK HEI sector, professional bodies are actively engaged to support IR framework adoption and integrated report preparation (BUFDG, 2016; BUFDG, 2017).

The findings have important policy, practical and regulatory implications. First, the findings will allow policymakers to evaluate how HEIs voluntarily implemented IIRC guidelines and how HEIs increased their level of disclosure on IR content elements during the period of study as an evidence of implementing integrated thinking. This will allow policymakers to suggest the implementation of IIRC guidelines mandatory when they see the benefits of providing such disclosure on HEIs performance. Specifically, this suggests that 
appropriate a sector wide enforcement and compliance body, for instance, the British Universities Finance Directors Group (BUFDG), may take into account developing voluntary IR guidance in a clear, consistent, concise and comparable format. Also, it may pursue regulatory support for this guidance. In doing so, it may monitor the compliance and disclosure levels of appropriate IR requirements. By supporting this approach, IR can help HEIs to capture more sustainable choices and allow stakeholders to better understand HEI performance. Second, integrated reporting and thinking of pre-1992 universities, which may produce an efficient and productive capital allocation, may operate as a force for financial strength and sustainability. This implies that pre-1992 universities employ integrated reporting and thinking to gain powerful stakeholders such as prospective students, alumni, Students Loans Company (SLC), and employers in addition to new competitive and market environment (e.g., elimination of limits on the number of students that can be recruited by an HEI) support and expectations. Third, our result regarding governing board size implies that further governance reforms may lead to greater demand for IR disclosure, public accountability and transparency, largely through improved external regulatory examination and funding environments. Thus, providing disclosure on IR content elements will provide more information for a variety of stakeholders such as potential students, academics, and other stakeholders to learn about HEI activities and encourage international students to apply to HEIs because they will be more aware of HEI activities.

This study has some limitations. The use of the weighted index may need more simplification and may be affected by judgement in the selection of content, however, it has been used before (Cheung et al, 2010). The study is based on IR content elements only and could be extended to include the fundamental concept and basic principles of the IR framework. There are other factors that have a potentially crucial influence on HEI core activities (such as teaching and learning research and internationalisation) which have been omitted from this 
study. These factors should be examined in more depth by future researchers both nationally and internationally. Further research can also extend the exploration of the relationship between integrated thinking and integrated reporting. Additionally, we assumed that increased reporting on specific IR content elements 'suggesting that integrated thinking is present'. However, future research is needed to investigate whether HEIs are implementing "greenwash" in when preparing content elements of IR documents without significantly altering their internal processes. 


\section{References}

Abed, S., Al-Najjar, B. and Roberts, C. (2016), "Measuring annual report narratives disclosure: Empirical evidence from forward-looking information in the UK prior to the financial crisis". Managerial Auditing Journal, Vol. 31 No. 4-5, pp. 338-361.

Abeysekera, I. (2013), “A template for integrated reporting”. Journal of Intellectual Capital, Vol. 14 No. 2, pp. 227-245.

Aburaya, R. (2012), The relationship between corporate governance and environmental disclosure: UK evidence. Doctoral dissertation, Durham University, available at: https://www.etheses.dur.ac.uk (accessed 3 January 2018).

Adams, C. (2018), Debate: Integrated reporting and accounting for suitable development across generations by universities. Public Money \& Management, Vol. 38 No 5, pp. 325 - 327.

Adams, C. (2017), "The Sustainable Development Goals, integrated thinking and the integrated report". [Online] Available from: https://www.integratedreporting.org/resources/sdgs-integrated-thinking-andthe-integrated-report/ [Accessed: $18^{\text {th }}$ November 2017].

Adams, C. (2015), "The International Integrated Reporting Council: A call to action". Critical Perspectives on Accounting, Vol. 27, pp. 23-28.Adams, C. (2017) "The Sustainable Development Goals, integrated thinking and the integrated report", available at: https://w ww.integratedreporting.org/resource/sdgs-integrated-thinking-and-the-integrated-report/ (accessed 18 November 2017).

Adams, C.A., Potter, B., Singh, P.J. and York, J. (2016), "Exploring the implications of integrated reporting for social investment (disclosures)". The British Accounting Review, Vol. 48 No. 3, pp. 283296.

Adams, S. and Simnett, R. (2011), "Integrated Reporting: An opportunity for Australia's not-for-profit sector". Australian Accounting Review, Vol. 21 No. 3, pp. 292-301.

Ahmed Haji, A. and Anifowose, M. (2017), "Initial trends in corporate disclosures following the introduction of integrated reporting practice in South Africa". Journal of Intellectual Capital, Vol. 18 No. 2, pp. 373-399.

$\mathrm{Al}$ - Htaybat, K. and Alberti - Alhtaybat, L. (2018), "Integrated thinking leading to integrated reporting: Case study insights form a global player". Accounting, Auditing \& Accountability Journal, Vol. 31 No 5, pp. $1435-1460$.

Alnabsha, A., Abdou, H. A., Ntim, C. G., \& Elamer, A. A. (2017). "Corporate boards, ownership structures and corporate disclosures: Evidence from a developing country". Journal of Applied Accounting Research, Vol 19 No 1, pp. 20-41.

Alsaeed, K. (2006), "The association between firm-specific characteristics and disclosure: The case of Saudi Arabia". Managerial Auditing Journal, Vol. 21 No. 5, pp. 476-496.

Asaad, Y., Melewar, T.C., Cohen, G. and MT Balmer, J. (2013), "Universities and export market orientation: An exploratory study of UK post-92 universities". Marketing Intelligence \& Planning, Vol. 31 No. 7, pp. 838-856. 
Ayoubi, R.M. and Massoud, H.K. (2007), "The strategy of internationalization in universities: A quantitative evaluation of the intent and implementation in UK universities". International Journal of Educational Management, Vol. 21 No. 4, pp. 329-349.

Badrul Muttakin, M, Khan, A. and Rahman Belal, A., (2015), "Intellectual capital disclosures and corporate governance: An empirical examination". Advances in Accounting, incorporating Advances in International Accounting, Vol. 31 pp. 219 - 227.

Berardino, D., D. and Corsi, C., (2018), "A quality evaluation approach to disclosing third mission activities and intellectual capital in Italian universities". Journal of Intellectual Capital, Vol. 19, No. 1, pp. $178-201$.

Berbegal-Mirabent, J. and Ribeiro-Soriano, D.E. (2015), "Behind league tables and ranking systems: a critical perspective of how university quality is measured". Journal of Service Theory and Practice, Vol. 25 No. 3, pp. 242-266.

Bezhani, I., “(2010), Intellectual capital reporting at UK universities”. Journal of Intellectual Capital, Vol. 11, No. 2, pp. $179-2017$.

Broecke, S. (2015), "University rankings: do they matter in the UK?" Education Economics, Vol.32 No. 2, pp. $137-161$.

BUFDG (2016), "Progress on the latest <IR $>$ project", available at: https://www.bufdg.ac.uk/resources/news/view?g=202eb51d-0903-4c1c-b3ab-9e2fle27e7f9 (accessed 15 August 2017).

BUFDG (2017), "Inside the International Integrated Reporting Conference", available at: https://www.bufdg.ac.uk/resources/news/view?g=5aaa723b-8345-4c22-afc7-7f9888182109 (accessed 3 January 2018).

Bukh, P., N., Nielsen, C., Gormsen, P. and Mouritsen, J. (2005), Disclosure of information on intellectual capital in Danish IPO prospectuses. Accounting, Auditing \& Accountability Journal. Vol. 18 No. 6, pp. $713-732$.

Burke, J.J. and Clark, C.E. (2016), “The business case for integrated reporting: insights from leading practitioners, regulators, and academics". Business Horizons, Vol 59 No. 3, pp. 273-283.

Busco, C., Frigo, M.L., Quattrone, P. and Riccaboni, A. (2013), "Towards integrated reporting: concepts, elements and principles", in Integrated Reporting, Springer, Cham., pp. 3-18.

Carpenter, V.L. and Feroz, E.H. (2001), "Institutional theory and accounting rule choice: an analysis of four US state governments' decisions to adopt generally accepted accounting principles". Accounting, Organizations and Society, Vol. 26 No. 7-8, pp. 565-596.

Chatelian - Ponroy, S. and Morin - Delerm, S. (2016), "Adoption of sustainable development reporting by universities: An analysis of French first - time reporters". Accounting, Auditing \& Accountability Journal, Vol. 29 No. 5, pp. 887 - 918.

Cheng, M., Green, W., Conradie, P., Konishi, N. and Romi, A. (2014), "The international integrated reporting framew ork: key issues and future research opportunities". Journal of International Financial Management \& Accounting, Vol. 25 No. 1, pp. 90-119. 
Cheung, Y.L., Jiang, P. and Tan, W. (2010), "A transparency disclosure index measuring disclosures: Chinese listed companies". Journal of Accounting and Public Policy, Vol.29 No. 3, pp. 259-280.

Christie, F. (2016), "The reporting of university league table employability rankings: a critical review". Journal of Education and Work, Vol. 30 No. 4, pp. 403-418.

Clegg, S. and Hardy, C. (2005), Studying Organisation Theory \& Method, Sage Publications, London, $\mathrm{UK}$.

Cooke, T., E. (1989), Voluntary Corporate Disclosure by Swedish Companies. Journal of International Financial Management \& Accounting. Vol. 1 No. 2, pp. $171-195$.

Coy, D. and Dixon, K. (2004), "The public accountability index: crafting a parametric disclosure index for annual reports". The British Accounting Review, Vol. 36 No. 1, pp. 79-106.

De Villiers, C., Rinaldi, L. and Unerman, J. (2014), "Integrated reporting: insights, gaps and an agenda for future research". Accounting, Auditing \& Accountability Journal, Vol. 27 No.7, pp.1042-1067.

Deloitte. (2014), “Annual report insights 2014: providing a clear steer", available at: https://www2.deloitte.com/uk/en/pages/audit/articles/annual-report-insights-2014.html (accessed 22 May 2016).

Dilnot, C. (2018), "The relationship between A - level subject choice and league table score of university attended: the 'facilitation', the 'less suitable', and the counter - intuitive". Oxford Review of Education, Vol. 44 No. 1, pp. 118 - 137.

Dragu, I.M. and Tiron-Tudor, A. (2013), "The integrated reporting initiative from an institutional perspective: emergent factors". Procedia-Social and Behavioral Sciences, Vol. 92, pp. 275-279.

Eccles, R.G. and Krzus, M.P. (2010), One report: Integrated reporting for a sustainable strategy. John Wiley \& Sons, New Jersey.Elmaghrabi, M.E.L. (2014) "the institutionalisation of integrated reporting: an exploration of adoption, sustainability embeddedness and decoupling", doctoral dissertation, Stirling University, available at: http://ethos.bl.uk/OrderDetails.do?uin=uk.bl.ethos.635511 (accessed 15 October 2017).

Elamer, A. A., \& Benyazid, I. (2018), The impact of risk committee on financial performance of UK financial institutions. International Journal of Accounting and Finance, Forthcoming. Available at SSRN: https://ssrn.com/abstract=3140917 (accessed 30 March 2018).

Elamer, A. A., Ntim, C. G., \& Abdou, H. A. (2017), Islamic governance, national governance, and bank risk management and disclosure in MENA countries. Business \& Society, https://doi.org/10.1177/0007650317746108 (accessed 30 March 2018).

Elmaghrabi, M.E.L. (2014), "the institutionalisation of integrated reporting: an exploration of adoption, sustainability embeddedness and decoupling", doctoral dissertation, Stirling University, available at: http://ethos.bl.uk/OrderDetails.do?uin=uk.bl.ethos.635511 (accessed 15 October 2017).

Feng, T., Cummings, L. and Tweedie, D. (2017), "Exploring integrated thinking in integrated reporting: an exploratory study in Australia". Journal of Intellectual Capital, Vol. 18 No. 2, pp. 330-353.

Ferrero-Ferrero, I., Fernández-Izquierdo, M.Á., Muñoz-Torres, M.J. and Bellés-Colomer, L. (2018), "Stakeholder engagement in sustainability reporting in higher education: an analysis of key internal 
stakeholders' expectations". International Journal of Sustainability in Higher Education, Vol. 19 No. 2, pp. 313-336.

Flower, J. (2015), "The international integrated reporting council: a story of failure". Critical Perspectives on Accounting, Vol. 27, pp. 1-17.

Fonseca, A., Macdonald, A., Dandy, E. and Valenti, P. (2011), "The state of sustainability reporting at Canadian universities". International Journal of Sustainability in Higher Education, Vol. 12 No. 1, pp. $22-40$.

Frías-Aceituno, J.V., Rodríguez-Ariza, L. and García-Sánchez, I.M. (2013), "Is integrated reporting determined by a country's legal system? An exploratory study". Journal of Cleaner Production, Vol. 44, pp. 45-55.

Gallego-Alvarez, I., Rodríguez-Domínguez, L. and García-Sánchez, I.M. (2011), "Information disclosed online by Spanish universities: content and explanatory factors". Online Information Review, Vol. 35 No. 3, pp. 360-385.

Garanina, T. and Dumay, J. (2017), "Forward-looking intellectual capital disclosure in IPOs: Implications for intellectual capital and integrated reporting". Journal of Intellectual Capital, Vol. 18 No. 1, pp. 128-148.

Gordon, T., Fischer, M., Malon, D. and Tower, G. (2002), A comparative empirical examination of extent of disclosure by private and public college and universities in the United States. Journal of Accounting and Public Policy. Vol. 21 No. 3, pp. 235 - 275.

Gibbons, S., Neumayer, E. and Perkins, R. (2015), "Student satisfaction, league tables and university applications: evidence from Britain". Economics of Education Review, Vol. 48, pp. 148-164.

Halsey, A. H. (2000), Further and higher education. In A. H. Halsey \& J. Webb (Eds.), Twentieth century British social trends. London: Macmillan

Hassan, A., Hunter, C. and Asekomeh, A. (2013), "The relationship between GRI Application levels and disclosure on specific environmental activities: an empirical investigation of top European Companies", Social and Environmental Accountability Journal, Vol. 33 No. 3, pp. 156-176.

Hair, J.F., Black, W.C., Babin, B.J., Anderson, R.E. (2013), Multivariate Data Analysis, $7^{\text {th }}$ ed. Pearson Education Limited, Harlow, Essex, United Kingdom.

Gunarathne, N. and Senaratne, S. (2017), "Diffusion of integrated reporting in an emerging South Asian (SAARC) nation”. Managerial Auditing Journal, Vol. 32 No. 4/5, pp. 524-548.

Higgins, C., Stubbs, W. and Love, T. (2014), "Walking the talk(s): Organisational narratives of integrated reporting". Accounting, Auditing \& Accountability Journal, Vol. 27 No.7, pp. 1090-1119.

Hinson, R., Gyabea, A. and Ibrahim, M. (2015), "Sustainability reporting among Ghanaian universities". South African Journal for Communication Theory and Research, Vol. 41 No. 1, pp. 2242.

Humphrey, C., O'Dwyer, B. and Unerman, J. (2017), "Re-theorizing the configuration of organizational fields: the IIRC and the pursuit of 'Enlightened' corporate reporting". Accounting and Business Research, Vol. 47 No.1, pp. 30-63. 
IFAC (2017), "Creating Value for SMEs Through Integrated Thinking", available at: https://integratedreporting.org/resource/ifac-creating-value-for-smes-through-integrated-thinking/ (accessed 6 March 2018).

IIRC (2013), "The Integrated Reporting Framework", available at: https://integratedreporting.org/resource/international-ir-framew ork/ (accessed 16 January 2016).

IIRC (2018), "Integrated Reporting <IR>”, available at: https://integratedreporting.org (accessed 15 February 2018).

Jensen, J.C. and Berg, N. (2012), "Determinants of traditional sustainability reporting versus integrated reporting. An institutionalist approach". Business Strategy and the Environment, Vol. 21 No. 5, pp. 299316.

Jiang, N. and Carpenter, V. (2013), "A case study of issues of strategy implementation in internationalization of higher education". International Journal of Educational Management, Vol. 27 No. 1 , pp. 4-18.

Joshi, M., Cabill, D., Sidhu, J. and Kansal, M. (2013), "Intellectual capital and financial performance: an evaluation of the Australian financial sector." Journal of Intellectual Capital, Vol. 14 No 2, pp. 264 -285 .

Katsikas, E., Rossi, F.M. and Orelli, R.L. (2016), Towards integrated reporting: Accounting change in the public sector. Springer International Publishing, Cham, Switzerland.

Khadaroo, M.I. (2005), "An institutional theory perspective on the UK's private finance Initiative (PFI) accounting standard setting process". Public Management Review, Vol.7 No. 1, pp. 69-94.

Kilıç, M. and Kuzey, C. (2018), "Determinants of forward-looking disclosures in integrated reporting". Managerial Auditing Journal, Vol. 33 No. 1, pp. 115-144

King Report III. (2009), "King report on governance for South Africa 2009", available at: https://www.iodsa.co.za/resource/resmgr/king_iii/King_Report_on_Governance_fo.pdf (accessed 20 May 2016).

King Report IV, (2016), Corporate governance for South Africa 2016. available at: https://www.oidsa.co.za/resource/resmgr/king/_iv_Report/IoDSA_King_IV_Report_-_WebVe.pdf (accessed 25 February 2018).

KPMG. (2016), "Room for improvement-The KPMG survey of Business Reporting”, $2^{\text {nd }}$ ed., available at: $\quad$ https://www.integratedreporting.org/resource/room-for-improvement-the-kpmg-survey-ofbusiness-reporting-second-edition/ accessed 22 February 2017).

Krippendorff, K. (2004), Content analysis: an introduction to its methodology, Sage Publications Ltd, London, UK.

Krizek, K., J., Newport, D., White, J. and Townsend, A. R. (2012), "Higher education`s sustainability imperative: how to practically respond?" International Journal of Sustainability in Higher Education, Vol. 13 No. 1, pp. $19-33$.

Kurochkina, I., Shuvalova, E. and Novozhilova, I. (2017), "About Formation of the Integrated Reporting Performance in the Process of Building a Sustainable Business of Transport and communication companies". Procedia Engineering, 178 No.2, pp, 267 - 277. 
Lang, M. and Lundholm, R. (1993), Cross - sectional Determinants of Analyst Rating of Corporate Disclosure. Journal of Accounting Research. Vol. 31 No. 2, pp. 246 - 271.

Larran Jorge, M. and Andrades Pena, F. J. (2014), "Determinant of corporate social responsibility and business ethics education in Spanish universities". Business Ethics: A European Review, Vol. 23 No 2, pp.139-152.

Larker, D., F. and Rustic us, T., O. (2010), "On the use of instrumental variables in accounting research.. Journal of Accounting and Economics, Vol. 49 No. 3, pp. 186 - 205.

Larker, D., F. and Rusticus, T., O., (2007), "Endogeneity and Empirical Accounting Research". European Accounting Review, Vol. 16 Issue 1, pp.207-215.

Liao, P.C., Xia, N.N., Wu, C.L., Zhang, X.L. and Yeh, J.L. (2017), "Communic ating the corporate social responsibility (CSR) of international contractors: Content analysis of CSR reporting". Journal of Cleaner Production, Vol. 156, pp. 327-336.

Lomas, L. (2006), "The locus of power in UK universities: its impact on educational development centres". Active Learning in Higher Education, Vol. 7 No. 3, pp. 243-255.

Low, M., Samkin, G. and Li, Y. (2015), "Voluntary reporting of intellectual capital: comparing the quality of disclosures from New Zealand, Australian and United Kingdom universities". Journal of Intellectual Capital, Vol. 16 No. 4, pp. 779-808.

Lozano, R. (2011), "The state of sustainability reporting in universities". International Journal of Sustainability in Higher Education, Vol. 12 No. 1, pp. 67-78.

Lozano, R. M. and Tirado-Valencia, P. (2016), "Do industrial companies respond to the guiding principles of the Integrated Reporting framew ork? A preliminary study on the first companies joined to the initiative. Spanish Accounting Review, Vol. 19 No. 2, pp. 252-260.

Lueg, K, Lueg, R., Andersen, K. A and Dancianu, V. (2016), "Integrated Reporting with CSR Practise". Corporate Communications: An International Journal, Vol. 21 No. 1, pp. 20 - 35.

Maingot, M. and Zeghal, D. (2008), "An analysis of voluntary Disclosure of Performance Indic ators by Canadian Universities". Tertiary Education and Management, Vol. 14 No. 4, pp. 269 -283.

Maringe, F. (2009), "Strategies and challenges of internationalisation in HE: An exploratory study of UK universities". International Journal of Educational Management, Vol. 23 No. 7, pp. 553-563.

Maroun, W. (2018), "Modifying assurance practic es to meet the needs of integrated reporting: the case for "interpretive assurance'". Accounting, Auditing \& Accountability Journal, Vol. 21 No. 2, pp. 400427.

Martin, R. and Austen, H. (1999), "The art of integrative thinking”, in Rotman Management, pp._2 - 5,

McNally, M., A. and Maroun, W. (2018), "It is not always bad news: Illustrating the potential of integrated reporting using a case study in the eco - tourism industry". Accounting, Auditing \& Accountability Journal, Vol. 31 No. 5, pp. 1319 - 1348.

Melloni, G., Caglio, A. and Perego, P. (2017), "Saying more with less? Disclosure conciseness, completeness and balance in Integrated Reports". Journal of Accounting and Public Policy, Vol. 36 No. 3, pp. 220-238. 
Menard, S. (2018), Applied Logistic Regression Analysis. $2^{\text {nd }}$ ed., Sage Public ations, London, UK.

Ntim, C.G. (2016), "Corporate governance, corporate health accounting, and firm value: The case of HIV/AIDS disclosures in Sub-Saharan Africa". The International Journal of Accounting, Vol. 51 No 2, pp.155-216.

Ntim, C.G., Soobaroyen, T. and Broad, M.J. (2017), "Governance structures, voluntary disclosures and public accountability: The case of UK higher education institutions", Accounting, Auditing \& Accountability Journal, Vol. 30 No. 1, pp. 65-118.

Nomura, K. and Abe, O. (2010), "Higher education for sustainable development in Japan: Policy and progress". International Journal of Sustainability in Higher Education, Vol. 13 No. 1, pp. 19 - 33.

Oliver, J., Vesty, G. and Brooks, A. (2016), "Conceptualising integrated thinking in practice". Managerial Auditing Journal, Vol. 31 No. 2, pp. 228-248

Paloma Sánchez, M., Elena, S. and Castrillo, R. (2009), "Intellectual capital dynamics in universities: a reporting model”. Journal of Intellectual Capital, Vol. 10 No. 2, pp. 307-324.

Pavlopoulos, A., Magnis, C. and Iatridis, G.E. (2017), "Integrated reporting: Is it the last piece of the accounting disclosure puzzle?" Journal of Multinational Financial Management, Vol. 41, pp. 23-46.

Perego, P., Kennedy, S. and Whiteman, G. (2016), "A lot of icing but little cake? Taking integrated reporting forward”. Journal of cleaner production, Vol. 136, pp. 53-64.

Reimsbach, D., Hahn, R. and Gürtürk, A. (2017), "Integrated reporting and assurance of sustainability information: an experimental study on professional investors' information processing". European Accounting Review, Vol. 26 No. 1, pp. 1-23.

Row bottom, N. and Locke, J. (2015), "The emergence of $<\mathrm{IR}>$ ". Accounting and Business Research, Vol. 46, No. 1, pp. $83-115$.

Sánchez, P., Elena, S. and Castrillo, R. (2009), "IntellectualCapital dynamics in universities: a reporting model”. Journal of Intellectual Capital, Vol. 10 No. 2, pp. 307 - 324.

Sangiorgi, D. and Siboni, B. (2017), "The disclosure of intellectual capital in Italian universities: What has been done and what should be done". Journal of Intellectual Capital, Vol. 18 No. 2, pp. 354-372.

Schmeltz, L. (2017), "Getting CSR communic ation fit: A study of strategically fitting cause, consumers and company in corporate CSR communication”. Public Relations Inquiry, Vol. 6 No. 1, pp. 47-72.

Soh, D.S., Leung, P. and Leong, S. (2015), "The development of integrated reporting and the role of the accounting and auditing profession”. In Social Audit Regulation, Springer, Cham., pp. 33-57.

Solomon, J. and Maroun, W. (2012), "Integrated reporting: the influence of King III on social, ethical and environmental reporting", available at: https://www.accaglobal.com/corporatereporting (accessed 2 December 2015).

Steenkamp, N. (2018), “Top 10 South African companies' disclosure of materiality determination process and material issues in integrated reports". Journal of Intellectual Capital, (in press) available at: https://doi.org/10.1108/JIC-01-2017-0002 (accessed 25 February 2018). 
Stubbs, W. and Higgins, C. (2014), "Integrated reporting and internal mechanisms of change". Accounting, Auditing \& Accountability Journal, Vol. 27 No. 7, pp. 1068-1089.

Yafele, A. (2012), Key Performance Indicator Disclosure by Large UK Private and Public Listed companies. PhD Thesis. Available from: https://ethos.bl.uk [Accessed: 16 ${ }^{\text {th }}$ January 2017].

Veltri, S. and Silvestri, A. (2015), "The Free State University integrated reporting: a critical consideration”. Journal of Intellectual Capital, Vol. 16 No. 2, pp. 443-462.

Wee, M., Tarca, A., Krug, L., Aerts, W., Pink, P. and Tilling, M. (2016), 'Factors affecting preparers' and auditors' judgements about materiality and conciseness in integrated reporting". ACCA, London, available at: https://www.accaglobal.com/corporatereporting (accessed 16 October 2017).

Zappettini, F. and Unerman, J. (2016), “'Mixing' and 'Bending': The recontextualisation of discourses of sustainability in integrated reporting”. Discourse \& Communication, Vol. 10 No. 5, pp. 521-542. 


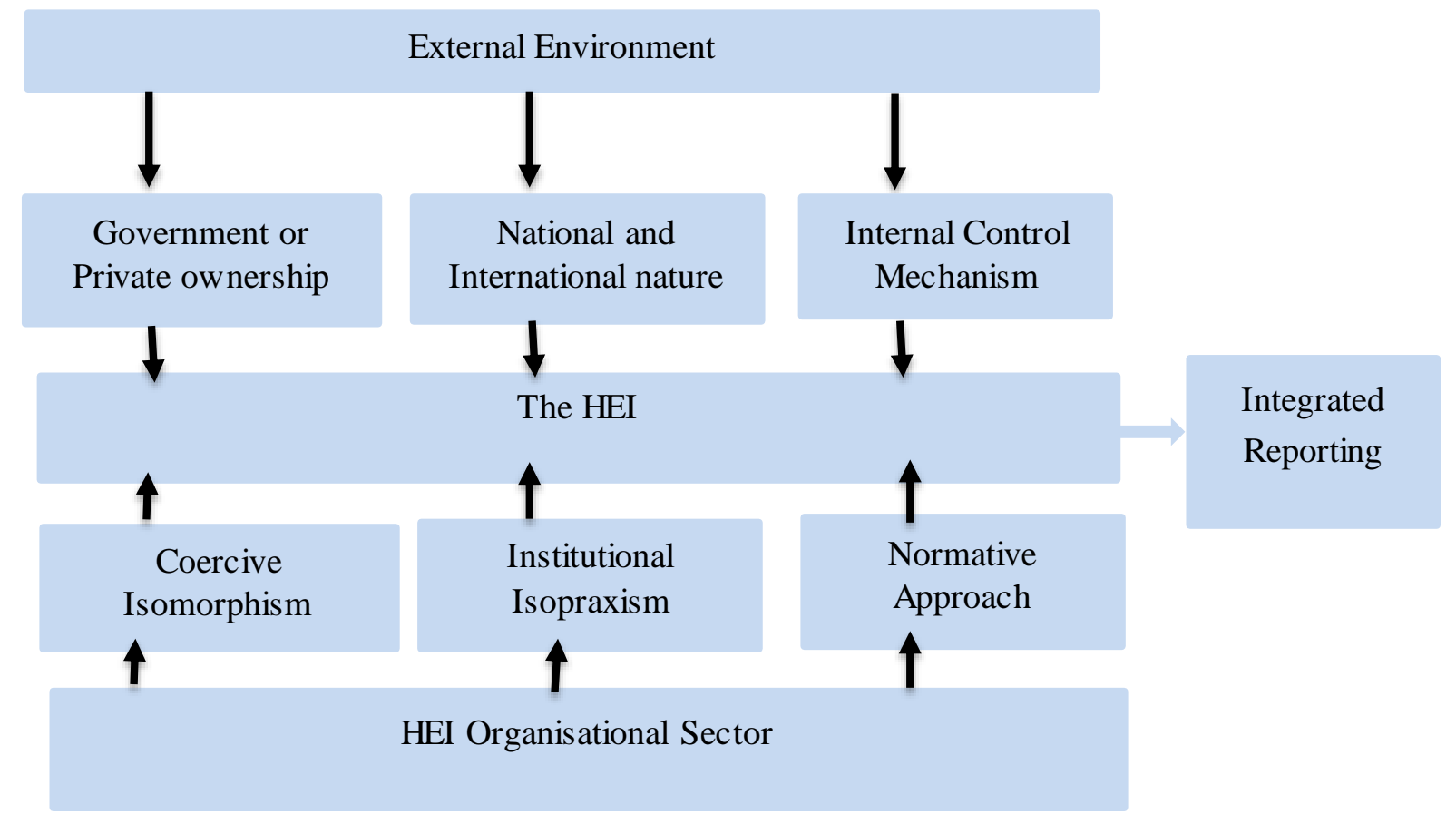

Figure: 1 Institutional factors and IR 


\section{Tables}

Table 1: Summary of variables and measurement

\begin{tabular}{|c|c|c|}
\hline Variables & Acronym & Definitions and coding. \\
\hline $\begin{array}{l}\text { Dependent } \\
\text { Variable: } \\
\text { Total IR } \\
\text { content } \\
\text { elements' } \\
\text { Disclosure } \\
\text { Score }\end{array}$ & TOTAL & $\begin{array}{l}\text { Total IR Content Elements Disclosure Score. Where, TOTAL - is the } \\
\text { IR content elements disclosure score containing } 56 \text { items based on } 8 \\
\text { main themes (see appendix } 1 \text { for more details), including: (1) } \\
\text { Organisational Overview and External Environment (OEE) including } \\
7 \text { items; (2) Governance (GVN) containing } 7 \text { items; (3) Value } \\
\text { Creation Model (VCM) covering } 7 \text { items; (4) Risk and Opportunity } \\
\text { (RO) entailing } 7 \text { items; (5) Strategy and Resource Allocation (SRA) } \\
\text { including } 7 \text { items; (6) Performance (PM) containing } 7 \text { items; ( } 7) \\
\text { Outlooks (OLK) covering } 7 \text { items and ( } 8 \text { ) Basis of Preparation and } \\
\text { Presentation (BPP) covering } 7 \text { items. All ( } 8 \text { themes X } 7 \text { items) } 56 \\
\text { items have a score threshold of } 0 \text { to } 3 \text {, resulting in a total potential } \\
\text { score of (56X3) 168. Where no disclosure = 0, descriptive disclosure } \\
\text { without any link to strategy, governance, performance and prospect = } \\
\text { 1, descriptive disclosure and link with all strategy, governance, } \\
\text { performance and prospect compare with historic position = } 2 \text {, } \\
\text { descriptive disclosure linked with all strategy, governance, } \\
\text { performance and prospect compare with historic, present and future } \\
\text { position = } 3 \text {. }\end{array}$ \\
\hline $\begin{array}{l}\text { Independent } \\
\text { Variables } \\
\text { related to } \\
\text { Higher } \\
\text { Education } \\
\text { sector } \\
\text { characteristics }\end{array}$ & $\begin{array}{l}\text { EST } \\
\text { IRDP } \\
\text { LTR } \\
\text { BSIZE }\end{array}$ & $\begin{array}{l}\text { Establishment of HEI: 1, If an HEI is established before 1992, } 0 \\
\text { otherwise; } \\
\text { Integrated Reporting Framework Adoption: 1, If an HEI adopted IR } \\
\text { Framework, } 0 \text { otherwise; } \\
\text { League Table Position Ranking: Measured by performance Position } \\
\text { Ranking in Complete University Guide League Table } \\
\text { Number of members in HEI governing board. }\end{array}$ \\
\hline $\begin{array}{l}\text { Control } \\
\text { Variables }\end{array}$ & $\begin{array}{l}\text { SIZE } \\
\text { GWTH } \\
\text { FUND } \\
\text { LIQD } \\
\text { TEA }\end{array}$ & $\begin{array}{l}\text { Size measured by Total Assets } \\
\text { Growth measured by the Percentage of current year's total income } \\
\text { minus previous year's total income to previous year's total income } \\
\text { Funding measured by Percentage of total annual council funding } \\
\text { income to total annual income } \\
\text { Liquidity measured by Current Assets divided by Current Liabilities } \\
\text { Total endowment measured by the Percentage of total annual } \\
\text { endowment assets to total annual assets. }\end{array}$ \\
\hline
\end{tabular}


Table 2: Descriptive statistics of study variables

\begin{tabular}{|l|l|l|l|l|}
\hline Variable & Means & Std. Dev. & Min & Max \\
\hline Dependent variable & 57.86 & 13.02 & 29.00 & 108.00 \\
\hline Total IR Score & 9.86 & 2.25 & 4.00 & 19.00 \\
\hline Theme (1) OEE & 8.94 & 2.08 & 0.00 & 13.00 \\
\hline Theme (2) GVN & 6.22 & 2.72 & 1.00 & 16.00 \\
\hline Theme (3) VCM & 6.31 & 2.79 & 0.00 & 15.00 \\
\hline Theme (4) RO & 8.49 & 2.71 & 1.00 & 17.00 \\
\hline Theme (5) SRA & 9.58 & 2.44 & 1.00 & 17.00 \\
\hline Theme (6) PM & 4.07 & 2.33 & 1.00 & 14.00 \\
\hline Theme (7) OLK & 4.47 & 1.44 & 2.00 & 12.00 \\
\hline Theme (8) BPP & 0.41 & 0.49 & 0.00 & 1.00 \\
\hline Independent variables & 0.02 & 0.15 & 0.00 & 1.00 \\
\hline EST & 53.64 & 38.55 & 0.00 & 126.00 \\
\hline IRDP & 24.50 & 6.15 & 10.00 & 45.00 \\
\hline LTR & \multicolumn{5}{l|}{} \\
\hline BSIZE & 36.62 & 332.21 & 0.00 & 6615.00 \\
\hline Control variables & 5.31 & 9.08 & -50.15 & 81.04 \\
\hline FUND & 1.97 & 1.15 & 0.24 & 8.20 \\
\hline GWTH & 544344.90 & 1124901.00 & 10619.00 & 11600000.00 \\
\hline LIQD & 3.00 & 5.09 & 0.00 & 28.37 \\
\hline SIZE &
\end{tabular}

Note. See Table 1 for more details on the disclosure score for each element. The minimum total score is zero and the maximum total score is 168 [ 8 elements $\times(7$ items per element $) \times 3$ (the score $)=168$ ] . The minimum score for each element is zero and the maximum for each element is $21(7 \times 3)$. 
Table 3: Total integrated reporting content elements' disclosure score

\begin{tabular}{|c|c|c|c|c|c|c|c|c|c|}
\hline \multirow[t]{2}{*}{ Variables } & \multicolumn{3}{|c|}{ Total sample } & \multicolumn{3}{|c|}{ Pre-1992(168) } & \multicolumn{3}{|c|}{ Post-1992(237) } \\
\hline & 2013/14 & $2014 / 15$ & $2015 / 16$ & 2013/14 & $2014 / 15$ & $2015 / 16$ & 2013/14 & $2014 / 15$ & $2015 / 16$ \\
\hline \multicolumn{10}{|c|}{ Total IR Score } \\
\hline Mean & 47.47 & 58.19 & 67.90 & 48.79 & 59.43 & 69.48 & 46.54 & 57.32 & 66.78 \\
\hline STD & 10.28 & 9.69 & 10.07 & 12.25 & 11.77 & 11.13 & 8.57 & 7.86 & 9.15 \\
\hline Min & 29.00 & 34.00 & 40.00 & 29.00 & 35.00 & 48.00 & 29.00 & 34.00 & 40.00 \\
\hline$\overline{\operatorname{Max}}$ & 88.00 & 96.00 & 108.00 & 88.00 & 96.00 & 108.00 & 66.00 & 71.00 & 96.00 \\
\hline \multicolumn{10}{|c|}{ Theme (1) OEE } \\
\hline Mean & 8.40 & 9.90 & 11.27 & 8.82 & 10.18 & 11.52 & 8.10 & 9.70 & 11.10 \\
\hline STD & 2.10 & 1.87 & 1.79 & 2.06 & 1.95 & 1.97 & 2.09 & 1.81 & 1.65 \\
\hline Min & 4.00 & 5.00 & 7.00 & 4.00 & 6.00 & 8.00 & 4.00 & 5.00 & 7.00 \\
\hline Max & 14.00 & 16.00 & 19.00 & 14.00 & 16.00 & 19.00 & 13.00 & 14.00 & 15.00 \\
\hline \multicolumn{10}{|c|}{ Theme (2) GVN } \\
\hline Mean & 7.78 & 9.04 & 9.99 & 7.89 & 9.14 & 9.80 & 7.70 & 8.97 & 10.13 \\
\hline STD & 2.10 & 1.85 & 1.64 & 2.34 & 1.78 & 1.59 & 1.92 & 1.91 & 1.67 \\
\hline Min & 0.00 & 4.00 & 5.00 & 0.00 & 6.00 & 7.00 & 4.00 & 4.00 & 5.00 \\
\hline Max & 12.00 & 13.00 & 13.00 & 12.00 & 13.00 & 13.00 & 12.00 & 12.00 & 13.00 \\
\hline \multicolumn{10}{|c|}{ Theme (3) VCM } \\
\hline Mean & 4.91 & 6.30 & 7.44 & 5.20 & 6.70 & 7.91 & 4.71 & 6.03 & 7.11 \\
\hline STD & 2.47 & 2.53 & 2.57 & 2.71 & 2.79 & 2.68 & 2.28 & 2.31 & 2.46 \\
\hline Min & 1.00 & 1.00 & 1.00 & 1.00 & 1.00 & 1.00 & 1.00 & 1.00 & 3.00 \\
\hline Max & 14.00 & 16.00 & 16.00 & 14.00 & 16.00 & 16.00 & 11.00 & 11.00 & 14.00 \\
\hline \multicolumn{10}{|c|}{ Theme (4) RO } \\
\hline Mean & 4.87 & 6.27 & 7.78 & 4.89 & 6.29 & 7.86 & 4.86 & 6.25 & $\overline{7.72}$ \\
\hline STD & 2.48 & 2.50 & 2.63 & 2.55 & 2.61 & 2.74 & 2.44 & 2.43 & 2.56 \\
\hline Min & 0.00 & 0.00 & 2.00 & 0.00 & 2.00 & 2.00 & 0.00 & 0.00 & 2.00 \\
\hline Max & 13.00 & 15.00 & 15.00 & 13.00 & 15.00 & 15.00 & 12.00 & 12.00 & 13.00 \\
\hline \multicolumn{10}{|c|}{ Theme (5) SRA } \\
\hline Mean & 6.59 & 8.67 & 10.20 & 6.79 & 8.82 & 10.30 & 6.46 & 8.57 & 10.13 \\
\hline STD & 2.46 & 2.06 & 2.30 & 2.83 & 2.44 & 2.54 & 2.17 & 1.75 & 2.14 \\
\hline Min & 1.00 & 4.00 & 5.00 & 1.00 & 4.00 & 5.00 & 2.00 & 5.00 & 6.00 \\
\hline Max & 13.00 & 14.00 & 17.00 & 13.00 & 14.00 & 17.00 & 12.00 & 13.00 & 16.00 \\
\hline \multicolumn{10}{|c|}{ Theme (6) PM } \\
\hline Mean & 8.17 & 9.54 & 11.02 & 8.41 & 9.66 & 11.13 & 8.00 & 9.46 & 10.95 \\
\hline STD & 2.23 & 2.21 & 2.02 & 2.22 & 2.05 & 2.05 & 2.24 & 2.32 & 2.01 \\
\hline Min & 4.00 & 1.00 & 5.00 & 4.00 & 6.00 & 6.00 & 4.00 & 1.00 & 5.00 \\
\hline Max & 14.00 & 14.00 & 17.00 & 14.00 & 14.00 & 17.00 & 13.00 & 14.00 & 16.00 \\
\hline \multicolumn{10}{|c|}{ Theme (7) OLK } \\
\hline Mean & 3.09 & 4.10 & 5.03 & 3.63 & 4.73 & 5.77 & 2.71 & 3.65 & 4.51 \\
\hline STD & 1.79 & 2.22 & 2.53 & 2.16 & 2.64 & 2.98 & 1.35 & 1.75 & 2.01 \\
\hline Min & 1.00 & 1.00 & 1.00 & 1.00 & 1.00 & 2.00 & 1.00 & 1.00 & 1.00 \\
\hline Max & 11.00 & 11.00 & 14.00 & 11.00 & 11.00 & 14.00 & 7.00 & 10.00 & 11.00 \\
\hline \multicolumn{10}{|c|}{ Theme (8) BPP } \\
\hline Mean & 3.79 & 4.47 & 5.16 & 3.84 & 4.50 & 5.13 & 3.76 & 4.44 & 5.19 \\
\hline STD & 1.34 & 1.35 & 1.29 & 1.35 & 1.39 & 1.15 & 1.35 & 1.34 & 1.39 \\
\hline Min & 2.00 & 2.00 & 2.00 & 2.00 & 2.00 & 2.00 & 2.00 & 2.00 & 3.00 \\
\hline Max & 6.00 & 6.00 & 12.00 & 6.00 & 6.00 & 6.00 & 6.00 & 6.00 & 12.00 \\
\hline
\end{tabular}


Table 4: Relationship between integrated reporting disclosure index and establishment of higher education institutions

\begin{tabular}{|c|c|c|c|c|c|c|c|c|}
\hline & \multicolumn{8}{|c|}{ Linking Disclosure items' themes to Establishment of HEI (EST) } \\
\hline & \multicolumn{2}{|c|}{ Pre-1992 (168) } & \multicolumn{2}{|c|}{ Post-1992 (237) } & \multicolumn{2}{|c|}{ T. test } & \multicolumn{2}{|c|}{ Mann-Whitney U test } \\
\hline & Mean & $\mathrm{St}$ & Mean & St & t. test & p-value & $\mathrm{Z}$ & p-value \\
\hline \multicolumn{9}{|l|}{ Integrated Reporting Content Elements (disclosure index components) } \\
\hline (1) Organisational Overview and External Environment (OEE) & 10.17 & 2.27 & 9.63 & 2.22 & -2.39 & $0.017 * *$ & -2.090 & $0.037 * *$ \\
\hline (2) Governance (GVN) & 8.95 & 2.08 & 8.93 & 2.08 & -.07 & 0.947 & -0.036 & 0.971 \\
\hline (3) Value Creation Model -Business Model (VCM) & 6.60 & 2.93 & 5.95 & 2.54 & -2.39 & $0.018 * *$ & -2.110 & $0.035 * *$ \\
\hline (4) Risk and Opportunity (RO) & 6.35 & 2.88 & 6.28 & 2.73 & -0.24 & 0.813 & -0.079 & 0.937 \\
\hline (5) Strategy and Resource Allocation (SRA) & 8.64 & 2.97 & 8.38 & 2.52 & -0.92 & 0.356 & -0.995 & 0.320 \\
\hline (6) Performance (PM) & 9.73 & 2.37 & 9.47 & 2.49 & -1.07 & 0.285 & -0.710 & 0.478 \\
\hline (7) Outlook (OLK) & 4.71 & 2.74 & 3.62 & 1.87 & -4.75 & $0.000 * * *$ & -3.471 & $0.001 * * *$ \\
\hline (8) Basis of Preparation and Presentation (BPP) & 4.49 & 1.39 & 4.46 & 1.47 & -0.16 & 0.869 & -0.400 & 0.689 \\
\hline Total Integrated Reporting (IR) Content elements score & 59.23 & 14.41 & 56.88 & 11.88 & -1.79 & $0.074 *$ & -1.384 & 0.166 \\
\hline
\end{tabular}

Note. Significance levels: $p<.10 .{ }^{*} p<.05 .{ }^{* *} p<.01 .{ }^{* * *}$. 
Table 5: Correlation matrix for research variables

\begin{tabular}{|c|c|c|c|c|c|c|c|c|c|c|}
\hline & Total & EST & IRDP & LTR & BSIZE & FUND & GWTH & LIQD & SIZE & TEA \\
\hline Total & 1.000 & & & & & & & & & \\
\hline$\overline{\text { EST }}$ & 0.089 & 1.000 & & & & & & & & \\
\hline IRDP & $0.172 * *$ & 0.077 & 1.000 & & & & & & & \\
\hline LTR & 0.003 & $-0.513 * *$ & -0.026 & 1.000 & & & & & & \\
\hline BSIZE & -0.027 & $0.313^{* *}$ & -0.031 & $-0.168 * *$ & 1.000 & & & & & \\
\hline FUND & 0.063 & -0.046 & -0.002 & 0.088 & 0.021 & 1.000 & & & & \\
\hline GWTH & -0.032 & $0.157 * *$ & -0.040 & $-0.211 * *$ & 0.057 & 0.004 & 1.000 & & & \\
\hline LIQD & 0.010 & $-0.291 * *$ & 0.035 & 0.075 & $-0.176^{* *}$ & -0.031 & -0.054 & 1.000 & & \\
\hline$\overline{\text { SIZE }}$ & $0.139 * *$ & $0.172 * *$ & 0.067 & $-0.306 * *$ & -0.071 & -0.023 & -0.010 & -0.078 & 1.000 & \\
\hline TEA & -0.048 & $0.493 * *$ & $0.155^{*}:$ & $-0.394 * *$ & $0.214 * *$ & -0.033 & 0.079 & $-0.189 *=$ & 0.303 *** & 1.000 \\
\hline
\end{tabular}

Note. The above table contains Pearson`s Parametric correlation coefficients, Significance levels: $p<.05^{*} . p<.01^{* *}$. Variables are defined as

follows: Total IR disclosure (TOTAL), Establishment of HEI (EST), Integrated reporting framework adoption (IRDP), League table position ranking (LTR), Number of members in HEI governing board (BSIZE), Funding (FUND), Growth (GWTH), Liquidity (LIQD), Total assets (SIZE), Total endowment (TEA). 
Table 6: Influence of HEI s pe cific characteris tics on IR dis clos ure

\begin{tabular}{|c|c|c|c|c|}
\hline Variables & (1) OLS & (2) RE & (3) $2 \mathrm{SLS}$ & (4) Lagged \\
\hline \multicolumn{5}{|c|}{ Panel A: Independent variables } \\
\hline \multirow[t]{2}{*}{ EST } & $3.622 * * *$ & $6.355 * * *$ & $5.072 * * *$ & $3.966 * * *$ \\
\hline & $(2.80)$ & $(3.00)$ & $(3.01)$ & $(2.60)$ \\
\hline \multirow[t]{2}{*}{ IRDP } & $15.117^{* * *}$ & $15.351^{* * *}$ & $15.234 * * *$ & $18.944 * * *$ \\
\hline & $(4.57)$ & $(2.74)$ & $(3.52)$ & $(4.89)$ \\
\hline \multirow[t]{2}{*}{ LTR } & 0.013 & 0.035 & 0.025 & $0.030^{*}$ \\
\hline & $(0.87)$ & $(1.44)$ & $(1.22)$ & $(1.66)$ \\
\hline \multirow[t]{2}{*}{$\overline{B S Z E}$} & 0.016 & 0.039 & 0.026 & 0.069 \\
\hline & $(0.19)$ & $(0.30)$ & $(0.24)$ & $(0.70)$ \\
\hline \multicolumn{5}{|c|}{ Panel B: Control variables } \\
\hline \multirow[t]{2}{*}{ FUND } & 0.001 & $0.003^{*}$ & 0.003 & 0.007 \\
\hline & $(0.90)$ & $(1.72)$ & $(1.35)$ & $(0.79)$ \\
\hline \multirow[t]{2}{*}{ GWTH } & -0.020 & -0.021 & -0.031 & -0.037 \\
\hline & $(-0.36)$ & $(-0.28)$ & $(-0.44)$ & $(-0.60)$ \\
\hline \multirow[t]{2}{*}{ LIQD } & -0.054 & 0.834 & 0.371 & 0.257 \\
\hline & $(-0.12)$ & $(1.27)$ & $(0.64)$ & $(0.45)$ \\
\hline \multirow[t]{2}{*}{ SIZE } & $0.000 * * *$ & $0.000 * * *$ & $0.000^{* * * *}$ & $0.000 * * *$ \\
\hline & (3.08) & $(3.42)$ & $(3.30)$ & $(3.91)$ \\
\hline \multirow[t]{2}{*}{ TEA } & $-0.299 * * *$ & $-0.614 * * *$ & $-0.460^{* * *}$ & $-0.269^{* *}$ \\
\hline & $(-2.60)$ & $(-3.34)$ & $(-3.07)$ & $(-2.08)$ \\
\hline \multirow[t]{2}{*}{ _cons } & $56.405^{* * *}$ & $52.720 * * *$ & $54.357 * * *$ & $61.835^{* * *}$ \\
\hline & $(19.76)$ & $(12.59)$ & $(15.25)$ & $(18.42)$ \\
\hline Years & Included & Included & Included & Included \\
\hline F-value $(\chi 2)$ & $31.41^{* * *}$ & $35.97 * * *$ & $4.09 * * *$ & $12.43^{* * *}$ \\
\hline $\mathrm{N}$ & 405 & 405 & 405 & 270 \\
\hline R-sq & 0.47 & & 0.09 & 0.32 \\
\hline adj. R-sq & 0.45 & & 0.06 & 0.30 \\
\hline
\end{tabular}

Notes: The above table represents regression coefficients and $t$ statistics in parentheses. Significance levels are $* \mathrm{p}<0.10$, ** $\mathrm{p}<0.05$, *** $\mathrm{p}<0.01$. The Variables are defined as follows. Total IR disclosure (TOTAL), Establishment of HEI (EST), Integrated reporting framework adoption (IRDP), League table position ranking (LTR), Number of members in HEI governing board (BSIZE), Funding (FUND), Growth $(G W T H)$, Liquidity (LIQD), Total assets $(S I Z E)$, Total endowment (TEA). 
Appendix 1: Integrated Reporting Content Disclosure Index*

\begin{tabular}{|c|c|c|c|c|c|c|}
\hline 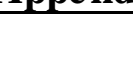 & & $\mathbf{0}$ & 1 & 2 & $3 * *$ & Source of index \\
\hline & $\begin{array}{l}\text { Organisational Overview and External } \\
\text { Environment (OEE) }\end{array}$ & & & & & \\
\hline OEE1 & Vison and Mission (VM) & & & & & $\begin{array}{l}\text { IR framework 2013; } \\
\text { BUFDG, 2016; Low et al., } \\
2015\end{array}$ \\
\hline OEE2 & $\begin{array}{l}\text { Operating structure, Principle Activates } \\
\text { and Market Position }\end{array}$ & & & & & $\begin{array}{l}\text { IR framework 2013; } \\
\text { BUFDG, } 2016\end{array}$ \\
\hline OEE3 & $\begin{array}{l}\text { Competitive environment and institution`s } \\
\text { position(CEP) }\end{array}$ & & & & & $\begin{array}{l}\text { IR framework 2013; } \\
\text { BUFDG, 2016; Gallego - } \\
\text { Alvarez et al., } 2011\end{array}$ \\
\hline OEE4 & Key quantitative information(KQI) & & & & & $\begin{array}{l}\text { IR framework 2013; } \\
\text { BUFDG, 2016; Low et al., } \\
2015\end{array}$ \\
\hline OEE5 & $\begin{array}{l}\text { Commercial, social, technical, } \\
\text { environment and political } \\
\text { environment(STPE) }\end{array}$ & & & & & $\begin{array}{l}\text { IR framework 2013; } \\
\text { BUFDG, 2016; Gallego - } \\
\text { Alvarez et al., } 2011\end{array}$ \\
\hline OEE6 & Revenue and change on it (RC) & & & & & $\begin{array}{l}\text { IR framework 2013; } \\
\text { BUFDG, 2016; Sanchez et } \\
\text { al., } 2009\end{array}$ \\
\hline OEE7 & $\begin{array}{l}\text { External environment and its impact on } \\
\text { value creation(EEVC) }\end{array}$ & & & & & $\begin{array}{l}\text { IR framework 2013; } \\
\text { BUFDG, } 2016\end{array}$ \\
\hline & Governance (GVN) & & & & & \\
\hline GVN1 & $\begin{array}{l}\text { Leadership structure, diversity and } \\
\text { regularity requirement(LDR) }\end{array}$ & & & & & $\begin{array}{l}\text { IR framework 2013; } \\
\text { BUFDG, 2016; Ntim et } \\
\text { al., } 2017\end{array}$ \\
\hline GVN2 & Different element and interaction (DEI) & & & & & $\begin{array}{l}\text { IR framework 2013, } \\
\text { BUFDG, 2016; Ntim et } \\
\text { al., } 2017\end{array}$ \\
\hline GVN3 & $\begin{array}{l}\text { Executive and non-executives`role and } \\
\text { responsibilities(ENR) }\end{array}$ & & & & & $\begin{array}{l}\text { IR framework 2013; } \\
\text { BUFDG, } 2016\end{array}$ \\
\hline GVN4 & Strategic decision-making process(SDM) & & & & & $\begin{array}{l}\text { IR framework 2013; } \\
\text { BUFDG, } 2016\end{array}$ \\
\hline GVN5 & $\begin{array}{l}\text { Monitoring approach of strategic direction } \\
\text { (MASD) }\end{array}$ & & & & & $\begin{array}{l}\text { IR framework 2013; } \\
\text { BUFDG, } 2016\end{array}$ \\
\hline GVN6 & $\begin{array}{l}\text { Risk identification, monitoring and } \\
\text { mitigation(RIMM) }\end{array}$ & & & & & $\begin{array}{l}\text { IR framework 2013; } \\
\text { BUFDG, } 2016\end{array}$ \\
\hline \multirow[t]{2}{*}{ GVN7 } & $\begin{array}{l}\text { Directors remuneration determination } \\
\text { process(DRD) }\end{array}$ & & & & & $\begin{array}{l}\text { IR framework 2013; } \\
\text { BUFDG, } 2016\end{array}$ \\
\hline & $\begin{array}{l}\text { Value Creation Model -B usiness Model } \\
\text { (VCM) }\end{array}$ & & & & & \\
\hline VCM1 & $\begin{array}{l}\text { Main activities, strategic purpose } \\
\text { achievement and value creation (APVA) }\end{array}$ & & & & & $\begin{array}{l}\text { IR framework 2013; } \\
\text { BUFDG, } 2016\end{array}$ \\
\hline VCM2 & $\begin{array}{l}\text { Different capitals utilization to complete } \\
\text { main activities (CUA) }\end{array}$ & & & & & $\begin{array}{l}\text { IR framework 2013; } \\
\text { BUFDG, 2016; Low et al., } \\
2015\end{array}$ \\
\hline VCM3 & Main source of income (IS) & & & & & $\begin{array}{l}\text { IR framework 2013; } \\
\text { BUFDG, } 2016\end{array}$ \\
\hline
\end{tabular}




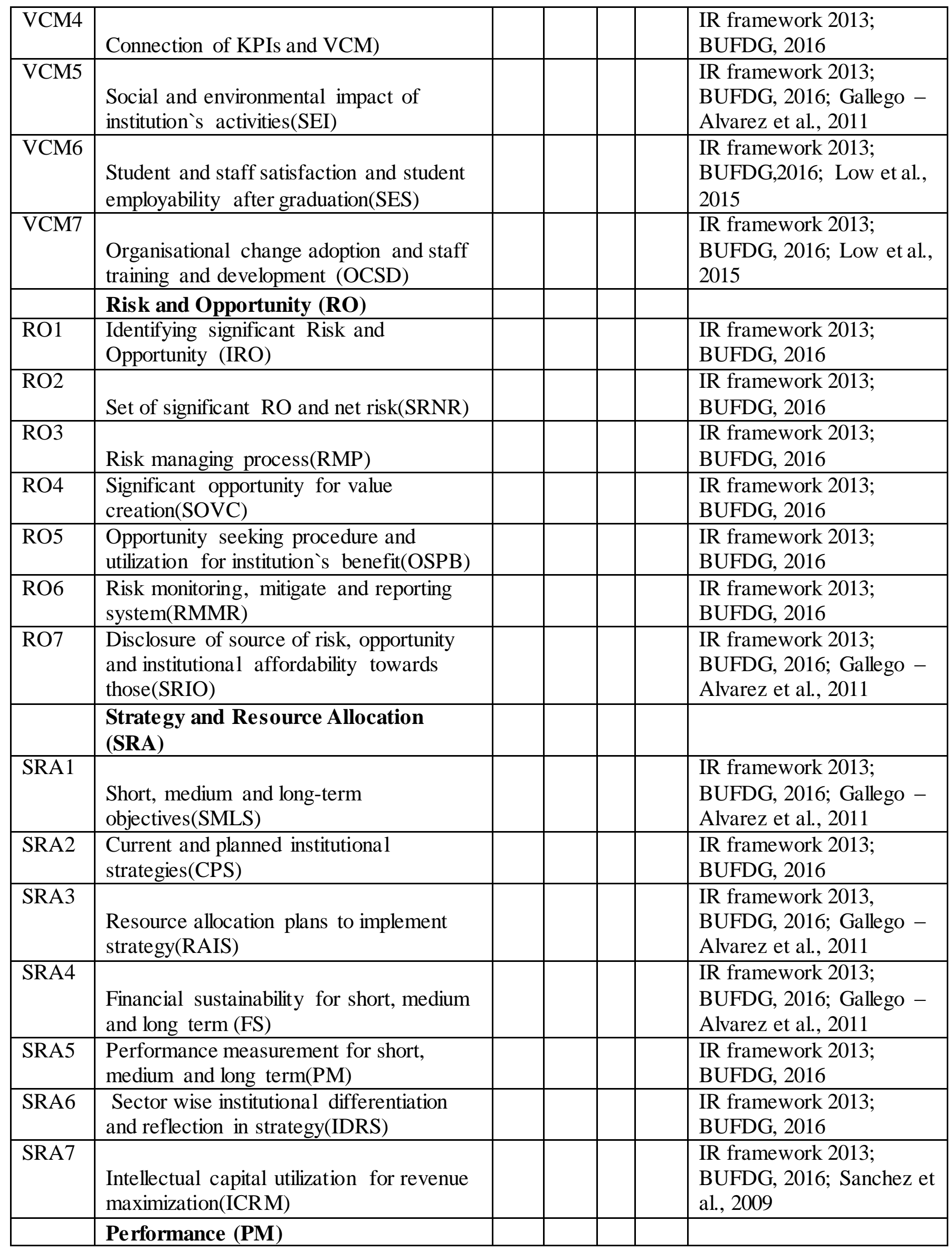




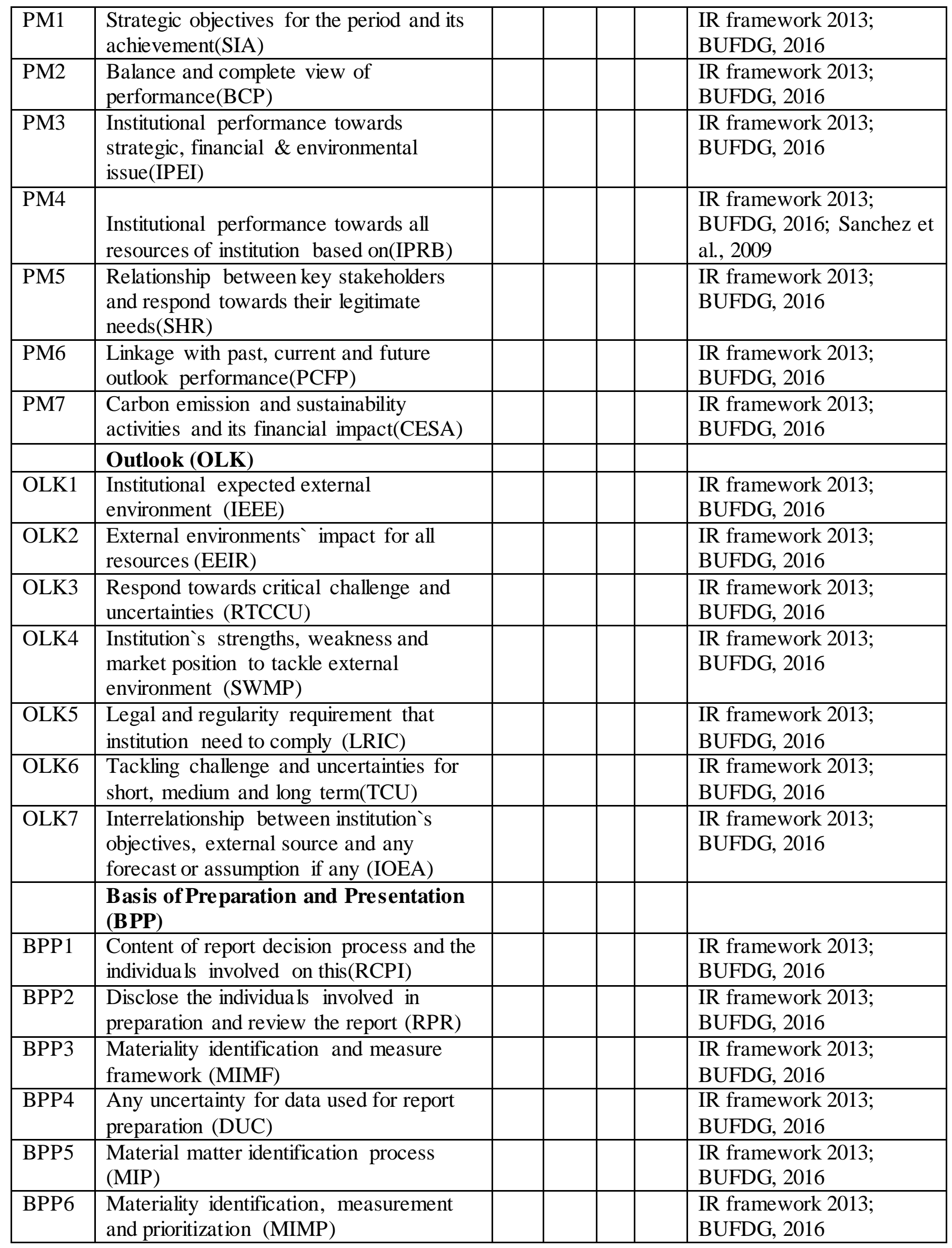




\begin{tabular}{|l|l|l|l|l|l|l|}
\hline BPP7 & $\begin{array}{l}\text { How institutions focus on value creation } \\
\text { form material matter (IFM) }\end{array}$ & & & & $\begin{array}{l}\text { IR framework 2013; } \\
\text { BUFDG, 2016 }\end{array}$ \\
\hline
\end{tabular}

*This disclosure index is adapted from the IIRC report (2013).

$* *$ No disclosure $=0$, Descriptive disclosure without any link to strategy, governance, performance and prospect $=1$, Descriptive disclosure and link with all strategy, governance, performance and prospect compare with historic position $=2$, Descriptive disclosure linked with all strategy, governance, performance and prospect compare with historic, present and future position $=3$ 